Elsevier required licence: (c) 2018. This manuscript version is made available under the CC-BY-NC-ND 4.0 license http://creativecommons.org/licenses/by-nc-nd/4.0/

The definitive publisher version is available online at https://doi.org/10.1016/j.jclepro.2018.05.140 


\title{
Industrial Sustainability: Modelling Drivers and Mechanisms with Barriers
}

\author{
Neri Alessandra ${ }^{a}{ }^{*}$, Cagno Enrico $^{a}$, Di Sebastiano Giulio $^{a}$, Trianni Andrea ${ }^{b}$ \\ ${ }^{a}$ Department of Management Economics and Industrial Engineering, Politecnico di Milano, 20133 Piazza Leonardo da \\ Vinci 32, Milan, Italy \\ ${ }^{b}$ School of Systems, Management and Leadership, Faculty of Engineering and Information Technology, University of \\ Technology Sydney, 181 Broadway, Ultimo NSW 2007 \\ *Corresponding author Tel.: +3902 23994095 e-mail address: alessandra.neri@polimi.it
}

\section{Highlights}

- Model of drivers to the adoption of industrial sustainability measures

- Model of mechanisms between drivers and barriers and between drivers

- Application in Italy manufacturing firms

\begin{abstract}
Sustainability's relevance is constantly increasing among industrial decision makers, policy-makers and scholars. To improve sustainability performance, firms must adopt industrial sustainability measures. These have been proven to positively impact on overall firm's performance, but their rate of adoption is still low, and barriers to their adoption need to be properly tackled by drivers. This work is based on a review of literature on drivers to sustainability and to the areas of occupational health and safety, eco efficiency, and energy efficiency, and contributes to industrial sustainability research presenting a novel framework of drivers. The framework comprehends a model of drivers and a model of mechanisms: the former encompasses previous literature contributions and aims to characterize drivers for the adoption of measures in all areas of industrial sustainability; the latter aims to evaluate if a driver may tackle specific barrier or boost the action of another driver.

We conducted a preliminary validation of the framework in nine Italian manufacturing firms. Regarding model of drivers, capacity to represent, usefulness and ease of use were evaluated; concerning model of mechanisms usefulness and ease of use were evaluated. Results seem to be sound with an overall positive evaluation of the framework by all the interviewees. Model of drivers was appreciated for its structure and completeness, and for its ability to enhance knowledge and awareness; model of mechanisms was considered useful for properly foster the adoption of a measure within the firm. The framework could be useful for industrial decision makers and policy-makers to better direct resources and efforts to foster the adoption of industrial sustainability measures.
\end{abstract}

Keywords: Industrial sustainability; Drivers; Barriers; Mechanisms; Measures; Decision-making

\section{Introduction}

The real need to improve sustainability in industrial activities (Rademaekers et al., 2011) has spurred in recent years the interest of policy-makers and industrial decision makers (IDMs). Even if firms started to include sustainability at a strategic level (Gutowski et al., 2005), current modes of production cannot be considered sustainable, and significant changes are needed, at a technological, managerial, organizational and behavioural level (Blok et al., 2015). The Triple Bottom Line model (TBL) (Elkington, 1998) identifies sustainability as the intersection of three different pillars, namely economic, environmental and social. In the industrial context, we can refer to corporate sustainability 
(CS), industrial sustainability (IS) and manufacturing sustainability (MS). Basing on literature, CS is related to strategy (Lozano, 2015), MS to production system (Garetti and Taisch, 2012), while IS refers to an industrial plant level (i.e. not just the production line), and requires actions involving materials, products, processes, plants and production systems (Tonelli et al., 2013), besides an integration with the normal activity of the firm (Evans et al., 2009), for further details, please refer to (Trianni et al., 2017b). For these reasons we defined IS as the research domain of the present study. IS has been often identified by previous literature with the areas of occupational health and safety (OHS) (Charmondusit et al., 2014; De Araujo and Gomes De Oliveira, 2012; Weidema, 2006), and eco efficiency (EcoEff) (Alves and Dumke De Medeiros, 2015; Gimenez et al., 2012; Kleine and Von Hauff, 2009), with a growing relevance of energy efficiency (EnEff) issue within the latter, (Lee, 2015; Pehlken et al., 2015; Tonelli et al., 2013). OHS and EcoEff can be identified using the TBL model respectively as the intersections of social and economic pillars, and environmental and economic pillars (Gimenez et al., 2012; Pagell and Gobeli, 2009).

To improve their sustainability, firms have to adopt measures in all IS areas, i.e. industrial sustainability measure (ISMs), as defined in (Trianni et al., 2017b). Although there is good evidence that such ISMs are effective and can impact positively on firms' performance (Fleiter et al., 2012; Norsiah et al., 2015; Tompa et al., 2009), many firms still struggle with their adoption. OHS is still considered one of the major challenges both for firms and policy-makers (Cagno et al., 2016), and there is a general recognition that the improvement of working conditions is a collective concern, driven by both humanitarian and economic considerations (Eurostat, 2016). The situation is critical also regarding EcoEff and EnEff: industrial sector is among the biggest consumers of resources and producers of waste (Eurostat, 2016). Even if ISMs have shown to positive affect economic and financial performance (Ambec and Lanoie, 2008; Fleiter et al., 2012), their adoption is still actually slow (Anderson and Newell, 2004; Vermeulen and Witjes, 2016).

In addition, industrial firms often care more about the economic impact of ISMs than social or environmental ones. Trade-offs have been largely identified (Salzmann et al., 2005) both between economic and environmental goals, and between economic and social ones (Beckmann et al., 2014; Haffar and Searcy, 2017). In particular, firms usually prioritize economic aspects over the others (Fennema, 2000; Van Der Byl and Slawinski, 2015), particularly in the short term (Lozano et al., 2015): pursuing only economic goals is, however, not enough to deliver long-term sustainability (Dyllick and Hockerts, 2002), for which it is necessary to also leverage on measures able to improve social and/or environmental performances, bringing relevant economic benefits as well (Henri and Journeault, 2009; Tanzil and Beloff, 2006).

The low rate of adoption of ISMs is due to barriers that make firms perceive ISMs as burdensome or unprofitable (Cherniack and Lahiri, 2010; Shi et al., 2008), or requiring too many organizational changes (Smith and Carayon, 2009; Martín-Peña et al., 2014). Barriers to IS and to its specific areas have been largely discussed in literature, and a novel model for barriers to IS has been recently developed by Trianni et al. (2017b). But, along with the barriers, one should understand the drivers that foster firms to adopt ISMs (Sudhakara Reddy et al., 2014), in particular, those that may help firms in implementing ISMs. Drivers can be seen both as the opposite of a barrier (Thollander and Ottosson, 2008) or as a mean to overcome barriers (Cagno et al., 2017). They can be both internal and external in origin, with reference to the firm (Sarkis et al., 2010), promoted by one or more stakeholders, and can influence organization and decision-making process (Trianni et al., 2017a). Taking inspiration from previous research (Trianni et al., 2017a), we can define an IS driver as "a factor promoted by one or more stakeholders, stimulating the adoption of an ISM, influencing a portion of the organization and a part of the decision-making process so to tackle existing barriers". Driver to single areas of IS have been largely discussed in literature, focusing on a specific industrial sector, geographical area or firm's dimension (Govindan et al., 2015; Pransky et al., 1999; Venmans, 2014), but none of these contributions has offered a comprehensive overview on drivers to IS. Indeed, contributions related to IS as a whole, like (Arruda et al., 2013), identify very few drivers and are less 
structured than contributions related to single areas. Recently, some authors considered the existence of mechanisms between drivers and barriers (Cagno et al., 2017; Trianni et al., 2017a, 2016) and between drivers (Lozano, 2015), while other authors (Cagno et al., 2015) identified also main actors involved in these mechanisms, but a formalization of the latter has not been developed yet.

The present work aims at developing a single, comprehensive framework for drivers to the adoption of ISMs, i.e. a model of drivers and a model of mechanisms between drivers and barriers, as well as between drivers. The model would be of considerable interest as it would underline possible interdependences among the different IS areas and highlight similarities and differences, developing an effective strategy for the identification of drivers fostering the adoption of ISMs; the model of mechanisms would rather capture how and to what extent either drivers are able to overcome or eliminate barriers, by means of mechanisms between drivers and barriers, or to boost the impact of another driver, by means of mechanisms between drivers. It is apparent how an enhanced knowledge of such mechanisms would be essential, on the one hand, for policy-makers to be more effective in designing regulations to improve the sustainability in the industrial sector, on the other hand, for IDMs to develop an improved understanding and awareness when evaluating the adoption of ISMs (Cagno and Trianni, 2014).

The remainder of the paper is structured as follows: in Section 2, literature review is conducted; in Section 3 the new framework, including the model of drivers and the model of mechanisms both between drivers and barriers, and between drivers, is introduced; in Section 4 research methods used for the validation of the model are reported, as well as the procedure for the evaluation of the validity of the model; in Section 5 the results obtained are reported and discussed. Lastly, conclusions are provided in Section 6, along with limitations of the study and possible further research.

\section{Literature review}

The literature review is divided into two parts. In the first part we briefly recap literature related to barriers to the adoption of ISMs, in the second part we focus on the review of the literature on drivers for the adoption of ISMs.

\subsection{Barriers to the adoption of ISMs}

Barriers to the adoption of ISMs has been recently discussed in literature by Trianni et al. (2017b). In particular, authors reviewed contributions related to the different areas of IS and to IS in the overall. They underlined that literature referred to single areas of IS had been largely developed. Indeed, for each area, research focused both on theoretical (Cagno et al., 2013; Hasle and Limborg, 2006; Silva Lopes et al., 2013) and empirical studies (Dobes, 2013; Mellor et al., 2011; Schleich, 2009). Moreover, different contexts have been taken into account in all the different areas, i.e. various industrial sectors (Chan, 2008; Okazaki and Yamaguchi, 2011; Whysall et al., 2006), diverse geographical areas (EASHW, 2010; Murillo-Luna et al., 2011; Venmans, 2014), and different firms' sizes (Kostka et al., 2013; Lamm, 1999; Zhang et al., 2009). Despite the considerable number of developed contributions on the topic, Trianni et al. (2017b) underlined that none of these studies offers a comprehensive overview on IS in the overall, pinpointing that research hitherto has been quite limited, as also noticed by Paramanathan et al. (2004). Some authors indeed have evaluated barriers to IS (Arevalo and Aravind, 2011; Frankental, 2001), underlying in particular difficulties in the integration of all the areas (Dyllick and Hockerts, 2002; Van Marrewijk, 2003), but contributions lack of a theoretical underpinning (Paramanathan et al., 2004), and are less structured than those applied to specific IS areas. Another interesting point underlined by Trianni et al. (2017b) is that barriers were addressed only at a general level, so without any reference to specific measures: Cagno and Trianni (2014) and Collins et al. (2010) started to evaluate barriers to specific measures, but they did it without an integrated approach, focusing respectively only on EnEff or on a different pillar of sustainability at a time. 
Summing up, Trianni et al. (2017b) developed a new theoretical model for barriers to IS, underlining possible interdependences among the different IS areas and taking the perspectives of the IDM considering the adoption of ISMs (Cagno et al., 2013; Trianni et al., 2013). Given the novelty of the work by Trianni et al. (2017b), as well as the comprehensive literature review conducted by the authors, we decided to take the proposed model, reported in Table 1, as the reference for this work.

\section{$<$ Table $1>>$}

\subsection{Drivers for the adoption of ISMs}

We carried out a background analysis of drivers to IS and of the different IS areas, so to obtain a better understanding of the extant literature. We searched for relevant literature querying international databases, i.e. SCOPUS, Google Scholar and ISI Web of Science. We also used snowball method, i.e. starting from a set of selected contributions, we searched for other relevant literature looking at references and citations of the initial set of selected contributions (Heckathorn and Cameron, 2017; Skolarus et al., 2017; Wohlin, 2014). Regarding keywords, we used combinations of driver and similar terms, e.g. driving force, fostering factor, combined with terms related to the different areas considered, i.e. IS, OHS, EcoEff, EnEff (for further details please refer to the specific literature analysis for each area). The first set of contributions obtained (articles, conference proceedings, books, and chapters) was very wide, showing in particular, a soaring importance of the topic in the last ten years. We decided to focus on contributions published in the last 20 years (1997-2017) and written in English, and to eliminate duplicates and contributions related to medicine in terms of surgery, medical operations and nursing. The remaining contributions were submitted to a title and abstract analysis, after which we obtained a deriving set of 152 contributions. This set was then submitted to a further refinement by a complete analysis of the text. In the end, 68 contributions were considered. In Table 2 contributions considered for the literature background analysis for each area are reported. In the following sections, we reported one reference for each driver identified in literature. The full list of references can be found in Table A1 of the Appendix.

$$
<\text { Table } 2>>
$$

\subsubsection{Drivers to $I S$}

Conducting the literature review related to drivers to IS, we focused both on IS and CS since the two concepts are often misled and to some extent interconnected: despite research is focused on IS, including CS offers a larger and more detailed analysis of existing literature (Trianni et al., 2017b). The discussion is characterized by both theoretical contributions (Schrettle et al., 2014) and empirical ones (Lloret, 2016), summarized in Table 2. Presence of both internal and external drivers with reference to the firm is pinpointed (Lozano, 2015).

Regarding external drivers, external pressures are recognized as ones of the main drivers. Pressures may be related to stakeholders (Fonseca, 2015), like pressure groups (Klewitz and Hansen, 2014), institutions and association (Santini et al., 2013), and customers (Kara et al., 2014). Legislation is considered a very important fostering factor as well (Sy, 2014), along with market, in the specific market opportunities (Küçüksayraç, 2015) and market differentiation (Gabzdylova et al., 2009). The importance of collaboration has been likewise underlined (Bocken et al., 2014). Considering internal drivers, business strategy was given a strong relevance (Koho et al., 2011), as well as long-term vision (Kara et al., 2014). Values (Klewitz and Hansen, 2014) and culture (Fonseca, 2015) result to be very important drivers, along with firm's image and reputation (Azapagic and Perdan, 2000). Management support and commitment are recognized as relevant (Santini et al., 2013), along with personal management satisfaction (Gabzdylova et al., 2009). Regarding employees, it is underlined the importance of satisfied ones (Merli et al., 2015). Lastly, the relevance of four other main drivers is pinpointed, i.e. product quality (Suriyankietkaew and Avery, 2016), innovation and technology 
(Bocken et al., 2014), economic benefits (Lloret, 2016), and resources scarcity (Schrettle et al., 2014). Empirical studies evaluate drivers in different contexts. Some of them focus on specific geographical areas, like Zealand (Collins et al., 2010) and Portugal (Fonseca, 2015), while others consider different sectors, such as heavy construction industry (Arruda et al., 2013) and wine industry (Gabzdylova et al., 2009). Lastly, some consider different sizes of firms, as SMEs (Suriyankietkaew and Avery, 2016) and LEs (Arruda et al., 2013).

\subsubsection{Drivers to Occupational Health and Safety $(\mathrm{OHS})$}

The discussion is characterized by both theoretical contributions (Hasle and Limborg, 2006) and empirical ones (Hale et al., 2010), as shown in Table 2. Contributions pinpoint the presence of both internal and external drivers with reference to the firm (EASHW, 2010). Regarding external drivers, the importance of regulation is underlined, in terms of tailored legislation (Antonsson et al., 2002), external economic incentives (Pransky et al., 1999), and compliance (Miller and Haslam, 2009). Relevance is also given to external support (Hasle and Limborg, 2006), in particular, collaboration (Cagno et al., 2016) and presence of networks (Antonsson et al., 2002), e.g. knowledge ones (Roy et al., 2003). Lastly, also the importance of suppliers' role is underlined (Walker and Tait, 2004).

Concerning internal drivers, the presence of rewards and internal incentives is a very strong fostering factor (Gangwar and Goodrum, 2005), as well as communication and dialogue within the firm (Hale et al., 2010), and integration of safety related measures in firm's daily activities (ENWHP, 2001). Regarding organization, several drivers are identified, such as motivation of employees (VecchioSadus and Griffiths, 2004), management (Sims, 2008), participation (ENWHP, 2001), training (Cagno et al., 2016) and presence and knowledge of examples (Kogi, 2006), as well as of an internal safety policy (Walker and Tait, 2004). Information and communication technology tools are considered an important boost for the adoption of measures (Cagno et al., 2016), as well as a business case approach (Miller and Haslam, 2009).

Empirical studies evaluate OHS drivers in different contexts. Some studies focus on specific geographical areas like UK (Tait and Walker, 2000) and Australia (Vecchio-Sadus, 2007), while others consider different sectors, like manufacturing (Pransky et al., 1999) and construction industry (Gangwar and Goodrum, 2005). Lastly, others consider different sizes of firms, as SMEs (Cagno et al., 2011) and LEs (Pransky et al., 1999).

\subsubsection{Drivers to Eco Efficiency (EcoEff)}

We included in our background analysis of drivers to EcoEff also contributions addressing concepts closely related to or overlapped with EcoEff, (Glavič and Lukman, 2007; Van Berkel, 2007), such as cleaner production (WBCSD and UNEP, 1998). Discussion about EcoEff drivers includes both theoretical contributions (Ekins, 2005) and empirical ones (Dagiliūtè and Juknys, 2012), as reported in Table 2. It is interesting to note that most of the contributions found in literature comprehend both a theoretical model and its empirical validation (Fernández-Viñé et al., 2013). Contributions pinpoint the presence of both internal and external drivers with reference to the firm (Bossle et al., 2016).

Concerning external drivers, regulatory pressure is considered one of the most important (Masurel, 2007), along with the will of avoiding sanctions (Ekins, 2005). Presence of public benefits (Santolaria et al., 2011) and financial incentives (Mittal and Sangwan, 2015) represent keys factors for the adoption of measures too. Market drivers are recognized as promoting factors, like an increase in resources price (Dagiliūtė and Juknys, 2012), resource scarcity (De Medeiros et al., 2014), improve of competitiveness (Fernández-Viñé et al., 2010), and new market opportunities (Del Río González, 2005). Other external drivers are related to pressures (Van Hemel and Cramer, 2002), and to market demand (Govindan et al., 2015). Supply chain may play an important role as well, in terms both of pressure (Mittal et al., 2013), and involvement (Hojnik and Ruzzier, 2016). Collaboration (De Medeiros et al., 2014), cooperation, (Bossle et al., 2016), and presence of an expert network, (Ghazilla 
et al., 2015) can foster the adoption of measures too. Regarding internal drivers, cost saving is for sure one of the main drivers, (Mittal et al., 2013), as well as efficiency (meant as the reduction in resources use) (Van Hemel and Cramer, 2002) and revenues (Hojnik and Ruzzier, 2016). An important role is played also by firm image (Del Río González, 2005), and by an opportunity of increasing market share (Bossle et al., 2016). Regarding the organization, main drivers have been identified with commitment (Govindan et al., 2015), competences (De Medeiros et al., 2014), values (Masurel, 2007), management concern (Bossle et al., 2016), and employees' demand (Govindan et al., 2015). Moreover, a clear strategy (Brammer et al., 2012), voluntary agreement (Hojnik and Ruzzier, 2016) and having a certification (Bossle et al., 2016) may foster the adoption of measures too. Other drivers identified refer to opportunities related to innovation (Ghazilla et al., 2015), research and development (De Medeiros et al., 2014), technology development (Mittal and Sangwan, 2015), reduction of risk (Van Hemel and Cramer, 2002), and increasing in product quality (Fernández-Viñé et al., 2013). Lastly, also information (Ekins, 2005) and past experiences (Hojnik and Ruzzier, 2016) are relevant drivers.

Empirical studies evaluate EcoEff drivers in different contexts. Some studies focus on specific geographical areas, like Venezuela (Fernández-Viñé et al., 2013, 2010), and India and Germany (Mittal et al., 2013), while others consider different sectors, like extractive metal, engineering, chemicals, printing and paper and timbering (Brammer et al., 2012) or manufacturing in general (Ghazilla et al., 2015). Lastly, others consider different sizes of firms, as SMEs (Altham, 2007) and LEs (Govindan et al., 2015)

\subsubsection{Drivers to Energy Efficiency (EnEff)}

Discussion about EnEff is very wide, nevertheless, most of the contributions are empirical, as Table 2 shows. Attempts to theoretically encompass drivers to energy EnEff recently emerged in (Trianni et al., 2017a) and (Johansson and Thollander, 2018). Contributions pinpoint the existence of both internal and external drivers, with reference to the firm (Apeaning and Thollander, 2013).

Regarding external drivers, policies (Anderson and Newell, 2004) and regulation (Sudhakara Reddy et al., 2014) are recognized as important fostering factors, along with subsidies (De Groot et al., 2001), public financing (Thollander et al., 2013), third parts financing (Rohdin et al., 2007) and taxes reduction (Sathitbun-anan et al., 2015). External pressures, like customers or NGO's ones, are relevant too (Lee, 2015), along with increasing in energy price (Abeelen et al., 2013). Presence of networks (Thollander and Ottosson, 2008), and the possibility to have support from experts (Lee, 2015) are considered important too. Lastly, international competition may foster the adoption of measures (Ren, 2009).

Concerning internal drivers, cost reduction is largely recognized as relevant (De Groot et al., 2001). Long term strategy (Brunke et al., 2014), firm's image (Aflaki et al., 2013), green concerns (Ren, 2009) and voluntary agreements (Lee, 2015) are relevant too. Moreover, people with real ambition (Rohdin et al., 2007), management vision and commitment (Thollander et al., 2013), and the adoption of an energy management system (Apeaning and Thollander, 2013) are considered important fostering factors. Lastly, other drivers have been taken into account, such as availability of information (Trianni et al., 2017a), development of technology (Venmans, 2014), increasing product quality (Hasanbeigi et al., 2010), reduction of risk (Venmans, 2014), improving working conditions (Sathitbun-anan et al., 2015), and non-energy benefits (Sudhakara Reddy et al., 2014).

Empirical studies evaluate EnEff drivers in different contexts. Some studies focus on specific geographical areas like Sweden (Rohdin and Thollander, 2006) or Korea (Lee, 2015), while others consider different sectors like textile and cement industry (Hasanbeigi et al., 2010) or printing (Masurel, 2007). Lastly, some consider different sizes of firms, as SMEs (Thollander et al., 2007), and SMEs and LEs together (Sathitbun-anan et al., 2015). 


\subsection{Emerging gaps}

Conducting the literature review, some interesting issues emerged. First, barriers and drivers may vary in the different steps of the decision-making process. This is considered for OHS (Masi et al., 2014; Saksvik et al., 2003), EnEff (Aflaki et al., 2013; Hasanbeigi et al., 2010), and EcoEff (Hojnik and Ruzzier, 2016). Second, the importance of taking in consideration the different perspectives of different decision makers when adopting a measure is highlighted (Cagno et al., 2018; Cagno and Trianni, 2014; Mittal and Sangwan, 2015), in line with Langley et al. (1995) that emphasizes the individual rather than the organizational level of analysis of the decision-making process, pinpointing that the process is driven mainly by personal insights and emotions. Indeed, because of their different backgrounds, aims and commitment, different decision makers may perceive different relevance of barriers and drivers to the adoption of specific measures (Sudhakara Reddy et al., 2014; Thollander and Palm, 2012). This is connected also to the complexity of the decision-making process for sustainability-related decision (Arvai et al., 2012; Gibson, 2006), connected in turn to different stakeholder requirements (Frini and Benamor, 2017; Gong et al., 2016; Nicolăescu et al., 2015). Third, the importance of considering mechanisms between drivers and barriers (Trianni et al., 2017a), as well as between drivers (Lozano, 2015), is underlined. Regarding mechanisms between drivers and barriers, they have been hitherto evaluated only with reference to EnEff: Sudhakara Reddy et al. (2014) underlined the need for understanding the relationship between drivers and barriers, to effectively assess the easiness and the proper way for tackling barriers; Cagno et al. (2015) defined the mechanism as a driver, promoted by a stakeholder, acting on a main barrier of a given decisionmaking step, considering also the different perceptions of the most relevant actors involved; Trianni et al. (2017a) proposed a framework for describing the effect of drivers on barriers in the decisionmaking process, as well as a preliminary identification of the major stakeholders to promote drivers, explaining in particular that a driver can act on a barrier with a certain strength along the whole decision-making process, and can also act simultaneously on another barrier, in all the different steps of the decision-making process, and the same for all the barriers; Cagno et al. (2017) conducted a further step specifying that the same driver could affect the same barrier with different strength in two separate steps of the decision-making process, a driver could tackle multiple barriers in a specific step with different strength and more drivers could affect the same barrier in a specific step.

Mechanisms between drivers have been evaluated, focusing on CS, by Lozano (2015) who stated there is a barrier that divides internal and external drivers for sustainability, depicting firms as closed systems: he thus proposed a new category of drivers, called 'connecting drivers', which can offer a more in-depth understanding of operant drivers, and help firm respond quickly to external drivers, thus promoting and rewarding internal ones.

Besides the previous considerations, after the literature review the lack of an integrated framework for drivers to the adoption of ISMs emerges. In particular:

1. There is a lack of a model of drivers for the adoption ISMs. Research to date has mainly evaluated drivers to IS by considering one area of IS at a time (Dagiliūte and Juknys, 2012; Lee, 2015; Sims, 2008), rather than taking a holistic perspective, and thus failed to take into account possible interdependencies. Contributions that have investigated drivers to IS as a whole, identified very few drivers with respect to those identified in single areas of IS (Lloret, 2016) and models and frameworks developed are less structured than those applied to specific single areas of IS (Sy, 2014). Moreover, almost all previous studies do not model drivers to specific ISM. The importance of underline specific barriers and drivers to the adoption of measures has been pinpointed by Trianni et al. (2017b), but so far contributions related to the topic just focused on barriers to EnEff measures (Cagno et al., 2018; Cagno and Trianni, 2014) or on one pillar of sustainability at a time, thus not considering all the areas of sustainability together (Collins et al., 2010). 
2. There is a lack of a comprehensive model for the identification of the mechanisms between drivers and barriers, and between drivers, since no contribution so far has modelled mechanisms between drivers and barriers and between drivers to IS as a whole: nevertheless, as stated by Cagno and Trianni (2014), modelling both mechanisms between drivers and barriers and between drivers themselves could provide a relevant contribution to the development of tailored policies and industrial practices.

\section{Development of a new framework for drivers and mechanisms}

\subsection{Development of the model of drivers}

Contributions related to the different areas of IS presented several commonalities, such as the distinction between external and internal drivers in origin, with further distinction into categories, quite helpful to shape the new model of drivers for the adoption of ISMs. Taking inspiration by huge body of extant literature, we reorganized drivers into internal and external, as well as within categories. The external drivers' categories we identified are: regulatory, support, external pressures, and market; the internal drivers' categories we identified are: organization, staff, information, innovation and economic.

Drivers affecting the three IS areas presented a considerable overlap; however, some differences are worth noting. We extended or adapted some driver's definition provided in literature, so to fit drivers referred in literature to one or two areas, to all the three areas and to IS in general. We found that some drivers could also apply to domains other than those cited. For instance, communities and partners' pressures were reported in literature as drivers for EcoEff (Del Río González, 2005), EnEff (Cagno and Trianni, 2013) and sustainability as a whole (Gabzdylova et al., 2009), but not for OHS: they may, however, also foster the adoption of OHS related measures; past experience and knowledge of business case was identified in literature as a driver for sustainability (Lozano, 2015), OHS (Kogi, 2006) and EcoEff (Hojnik and Ruzzier, 2016), but it can be a relevant driver for EnEff too; support from industrial association was considered by literature as relevant for OHS (Sims, 2008), EcoEff (Ghazilla et al., 2015), and EnEff (Lee, 2015), and it can be easily extended to sustainability as a whole; dialogue and encouragement was recognized by literature as an important driver for EnEff (Sathitbun-anan et al., 2015) and OHS (Vecchio-Sadus, 2007), but it may be relevant also to EcoEff and sustainability in general.

\subsection{Description of the drivers}

\subsubsection{External drivers}

Taking inspiration from previous literature (Gabzdylova et al., 2009; Hojnik and Ruzzier, 2016; Santini et al., 2013), an external driver has its origin externally to the firm and it is promoted by external stakeholders.

Regulatory

- Compliance with regulation: sustainability is subjected to legislation and governmental regulation, which firm must be compliant with (Van Hemel and Cramer, 2002);

- Regulatory sanctions and taxes: sanctions and taxes imposed by regulators to firms not achieving one or more sustainability performance thresholds (Hasle and Limborg, 2006).

\section{Support}

- External funding: presence of monetary support, e.g. loan from financial institution. It includes the so called third- part financing (Thollander et al., 2007);

- Public subsidies: creation of public monetary funds for firms (Mittal et al., 2013). 
- Cooperation and network with other companies: support to the adoption of ISMs provided by other companies. This support consists of sharing knowledge, resources and common initiatives (Jochem and Gruber, 2007; Walker and Tait, 2004);

- Support from industrial associations: support to the adoption of ISMs provided by industrial associations. This support consists of sharing knowledge, resources and common initiatives (Roy et al., 2003);

- Support from consultant: support provided by external consultants. This may consist in providing competences and knowledge (Antonsson et al., 2002);

- Support from government: support provided by government. This may consist in providing advice and information for the adoption of ISMs (Fernández-Viñé et al., 2013).

External Pressures

- Customers' pressures: customers' awareness on sustainability issues (Govindan et al., 2015);

- Communities' pressures: communities' awareness on sustainability issues (Mittal et al., 2013);

- Partners' pressures: commercial partners' awareness on sustainability issues (in particular other firms of the supply chain) (Govindan et al., 2015);

- Shareholders' pressures: shareholders' awareness on sustainability issues (Govindan et al., 2015);

- Competitors' actions: competitors have already adopted specific ISMs (Van Hemel and Cramer, 2002);

Market

- Public opinion: public opinion's awareness on sustainability issues (Govindan et al., 2015).

- Increase of market share and sales growth: prospect of increasing market share (Bossle et al., 2016);

- New market opportunities: prospect of new market opportunities (Bossle et al., 2016);

- Increasing in resources price: continuous and predictable increase in resources price (Sudhakara Reddy et al., 2014);

- Creating competitive advantage: when a firm see sustainability as a competitive tool, the topic is of primary importance to achieve business target (Bossle et al., 2016);

- Resources scarcity: depletion of natural resources and concerns on sustainability (Govindan et al., 2015).

\subsubsection{Internal drivers}

Basing on previous literature (Gabzdylova et al., 2009; Hojnik and Ruzzier, 2016; Van Hemel and Cramer, 2002), an internal driver has its origin internally to the firm and it is promoted by internal stakeholders, regardless the influence of external parties.

Organization

- Improving firm brand and image: reputation plays a vital role in any firm's growth. Hence to retain the firm image, the adoption of ISMs is mandatory (Govindan et al., 2015);

- Improvement of sustainability related performance: willingness of improving sustainability related performance (Hasanbeigi et al., 2010);

- Anticipation of regulatory changes: the desire of a firm to be compliant not only with the existing, but also with the upcoming regulation (Cagno and Trianni, 2013). Moreover, firms staying ahead of regulations can have a competitive edge over those struggling to keep up (Ekins, 2005);

- Organizational values and culture: firm's values and culture consistent with sustainability (Koho et al., 2011);

- Past experiences in sustainability and knowledge of business case: past experience in sustainability and availability of knowledge of effective business cases for sustainability (Sims, 2008); 
- Including sustainability at strategic level: in order to enhance sustainability, a major challenge for managers is the degree of integration of sustainability principles (such as in the form of strategy objectives, vision and mission) into the overall firm strategy (Schrettle et al., 2014), in particular with a long term perspective (Hasanbeigi et al., 2010);

- Adoption of certifications/ management systems: adoption of certifications and management systems (Bossle et al., 2016);

- Voluntary agreements: it results from the government public policies, or from the collaboration among different firms that enter into a contract bringing benefits in terms of sustainability (Venmans, 2014).

Staff

- Management commitment: committed management to enhance sustainability (Koho et al., 2011);

- Employee commitment: committed employees to enhance sustainability (Koho et al., 2011);

- Training and education: training and education programs increase the awareness and the knowledge of the personnel, who is thus more motivated to intervene or correctly behave (Walker and Tait, 2004).

\section{Information}

- Dialogue and encouragement: the principle of dialogue and encouragement is essential for team-working and community building, allowing people, tasks, processes and systems to interact purposively and co-operatively to sustainability objectives (Vecchio-Sadus, 2007);

- Availability, trustworthiness and clarity of information: to properly make a decision, firms should be provided with reasonable amount of relevant information. Indeed, even if available, information is often disaggregated and considered unreliable (Thollander et al., 2007).

\section{Innovation}

- Product innovation: implementing product innovation may help firm in improving its sustainability performance (Bossle et al., 2016);

- Technology innovation: adopting technology innovation may lead to improved sustainability performance (Del Río González, 2005);

- Quality: increasing quality may help firm in improving its sustainability performance (Fernández-Viñé et al., 2010);

- Greater efficiency in processes: the aim of increase process efficiency may foster firm in increasing also sustainability performance, i.e. a more efficient process consumes less resources (Masurel, 2007).

\section{Economic}

- Cost savings: prospect of a reduction in cost. More in detail, the cost saving is related to the reduction of resource use (EcoEff and EnEff) (Mittal et al., 2013; Thollander and Ottosson, 2008) and of accidents (OHS) (Tait and Walker, 2000);

- Increasing incomes: prospect of increasing incomes, in particular the profit maximizing objective served as an important stimulus (Sy, 2014).

\subsection{Development of the model of mechanisms}

Basing on the definition provided by Cagno et al. (2017, 2015) and Trianni et al. (2017a), we consider a mechanism as a relation between a driver and a barrier and/or another driver, prompted by a stakeholder, both internal or external to the firm, in a specific step of the decision-making process, considering also the different perspectives of the different IDMs. In particular, the driver can act both on a barrier and on other driver with a certain strength, and it can also act simultaneously on another barrier or driver, in all the steps of the decision-making process. Moreover, a driver could act on multiple barriers and drivers in a specific step with different strength, and more drivers could affect the same barrier or driver in a specific step. 
In our study, we focussed on the development of theoretical mechanisms with rationale presented in Figure 1 and details presented in the following. In particular, on the one hand, we consider drivers that may impact directly on a barrier; on the other hand, we consider drivers that may boost the impact of another driver on a barrier, thus acting as an enabler, as showed with further detail in the following.

$$
<<\text { Figure } 1>>
$$

\subsubsection{Mechanism between drivers and barriers}

A driver can tackle a barrier and this means that the driver can help the firm in the adoption of an ISM by reducing (or eliminating) the effect of the barrier. The mechanism between drivers and barriers is represented in Figure 2. In developing the mechanisms, we used the model for barriers to the adoption of ISMs proposed by Trianni et al. (2017b).

$$
<\text { Figure } 2>>
$$

For example, the new market opportunities driver is able to influence firm's attitude, and the presence of external funding, is able to influence both management and workers' awareness, as also observed in (Trianni et al., 2017a). It has been largely underlined, indeed, that attitude and other priorities, as well as the awareness can play a very relevant role in preventing the adoption of ISMs, see e.g. (EASHW, 2010; Murillo-Luna et al., 2011; Rohdin and Thollander, 2006).

Past experience in sustainability may then reduce the risk associated with the possible adoption of an ISM, since, given the experience, firm might be able to better identify and evaluate potential risks, as well as potential mitigation actions, see also (Morioka and Carvalho, 2014; Razali and Tahir, 2011).

\subsubsection{Mechanism between drivers}

Some drivers can activate the action of other drivers (Lozano, 2015). This type of drivers are named enabler drivers, since they enable another driver to foster the adoption of an ISM, i.e. they enable the driver to tackle barriers. This mechanism between drivers is represented in Figure 3. All external drivers are enablers; regarding internal drivers, they are divided in enablers and simple drivers: the internal enabler drivers can activate other internal drivers, whilst the simple ones can only act directly on barriers. All the enablers can both enable the action of another driver on a barrier, or directly tackle a barrier.

$$
<<\text { Figure } 3>>
$$

For instance, resource scarcity driver enables a greater process efficiency (driver), thus improving firm's sustainability. If the resources used by the firm for its process are scarce (e.g. rare earths), this would represent a push towards more efficient processes, as they may lead to a reduction in resources consumption. In turn, since scarce resources are usually subjected to price fluctuation and increase, such reduction in the use of resources (due to the more efficient processes), would lead to cost savings too. Improving company brand and image may foster the adoption of certifications, as well as voluntary agreements, in order to make stakeholders perceive the firm as committed to sustainability, see also (Murmura et al., 2018; Santos et al., 2017).

The model of drivers is reported in Table A1 of the Annex. For each driver, we indicated its origin and category, as well as references. In the last column, the type of driver is reported (i.e. enabler external, enabler internal or simple).

\section{Validation of the framework}

In order to assess the validity of the model of drivers and the model of mechanisms, we conducted nine case studies with audio-recorded semi-structured interviews, questionnaires, company visit and secondary material, within Italian manufacturing firms. Multiple sources of evidence have been gathered to increase the validity of the analysis (Voss et al., 2002; Yin, 2009). Manufacturing sector is indeed very important in Italy, and presents still ample room for further improvement in 
performance related to the different areas of IS (INAIL, 2014; Eurostat, 2016). The sample is thus heterogeneous by activity, size ${ }^{1}$ and turnover, and homogeneous regarding country (Morioka and Carvalho, 2014; Osagie et al., 2016). The sample size is suitable to provide evidence of the theoretical generalizability of an emerging theory (Eisenhardt, 1989), rather than statistical one (Hillebrand et al., 2001; Stuart et al., 2002), as previous research shows that a set from 6 up to 10 cases is considered as adequate for validating the initial set of propositions (Eisenhardt, 1989; Pagell and Wu, 2009). We chose to perform investigation interviewing twelve people in leadership positions in charge of EcoEff, EnEff and OHS, so to gather multiple perspectives on sustainability issues, as reported in Table 3.

$$
<\langle\text { Table 3>> }
$$

Data collection has been organized in three steps. First, we selected our research sample, starting from a database (AIDA, 2017) containing relevant industrial information, on the basis of firm sector, number of employees, and turnover. Upon their acceptance, after a preliminary contact by e-mail or phone, we gathered relevant secondary data (from e.g., firm websites, reports) regarding how those firms are structured, their production processes, as well as projects, initiatives, etc., towards increased IS.

Second, we conducted our investigation into the firms. Interviewees were asked to introduce the firm, focusing on sector, main production processes, number of employees, turnover and attitude toward sustainability. We then performed a plant tour, so to directly observe the status quo, as well as to identify possible problems related to IS areas. Finally, the main interview took place, by taking questionnaires as a guide, so to standardize the sequence in which the questions were asked and minimize the impact of contextual effects (Patton, 1990). We also asked several additional open-ended questions, supplemented by questions emerging during the interview, and free comments, as DiciccoBloom and Crabtree (2006) suggest. We presented the model of drivers to interviewees, describing every single driver. We asked interviewees to evaluate drivers for their firm and to specific ISMs considered for the adoption in their firm. Moreover, we asked interviewees to identify possible mechanisms between drivers and barriers and between drivers, both in general terms and concerning the adoption of specific ISMs considered in their firm. Furthermore, we asked interviewees to evaluate our framework according to three main performances, namely capacity to represent, usefulness and ease of use, as follows:

- capacity to represent: capacity of the proposed model to represent the full set of drivers to IS, drivers sufficiently distinct and with the same level of detail;

- usefulness: point out both "new" drivers (i.e. not hitherto aware of), better structure of current knowledge (drivers already identified), usefulness to design and implement ISMs, model as valuable support for drivers' identification, enhancing firms' knowledge and awareness;

- ease of use: effort paid to understand and apply the model.

Finally, regarding the model of mechanisms, we validated the mechanisms developed in theory as well as their usefulness and ease of use.

In the third step, we transcribed and coded interviews, also making a comparison with secondary data and other findings emerged during the interview, trying to identify possible misalignments. In case, we followed up with a second meeting (either face to face or phone) for further clarification.

\section{Results and discussion}

We based our model evaluation on the judgment of all interviewees (twelve), rather than on firms' overall judgments (nine), as in some case studies, interviewees from the same firm had differing

\footnotetext{
${ }^{1}$ We adopted the classification proposed in (European Union, 2003), i.e. we considered SMEs firms with a staff headcounts minor than 250, LEs firms with a staff headcounts equal or higher than 250 .
} 
opinions, as previous research shows (Cagno et al., 2018; Cooremans, 2012; Thollander and Palm, 2012).

Figure 4 shows that the results of the validation of the model of drivers were positive with respect to the three performances considered. Regarding capacity to represent, the model was judged complete and all the twelve interviewees considered the drivers specified in the model to be sufficiently distinct and detailed. Concerning usefulness, the model led the interviewees to identify hidden drivers and to better structure what they may have already in mind. The former aspect was underlined, for example, by OHS manager of Firm 6, who "never considered external drivers such as public opinion and community expectations, since our market is a B2B one. Nevertheless, now I do think it is necessary to consider them for having a complete view on drivers", and by OHS manager of Firm 1, who declared that "hitherto, firm underestimated some drivers, putting them in macro categories"; the latter aspect was pinpointed also by OHS manager of Firm 1, who considered the model exhaustive and detailed, and by technical director of Firm 4, who stated his firm has "a similar model but not so well structured and detailed". In addition, all the interviewees judged the model very useful for the designing and implementation of measures, and able to provide a valid and quick help for the identification of drivers. OHS manager of firm 6, for example, stated his firm already has "an internal model for the evaluation of drivers but for sure it needs to be integrated with yours", and OHS assistant of Firm 1 declared "model could be useful in sponsoring a project within the firm: it is possible to show pros and cons by a business plan". Interviewees underlined also that the model allowed them to have a complete view on the drivers, enhancing their knowledge and awareness; the model, indeed, as stated by health, safety and environment (HSE) manager of Firm 2 "is very useful to point out aspects usually faced, but not always considered or clearly identified. Considering also these aspects can help us in properly and better understanding all the implications related to the adoption of measures, thus basically enhancing our awareness on the topic".

Respecting ease of use, the model succeeded in the vast majority of interviewees, in particular, as HSE manager of Firm 5 said for the "concise but exhaustive view on drivers" the model is able to provide; it is worth noting that also who deemed the model as a little bit complex, offered here a quite positive judgment, highlighting however that it was worth using it because of the high quality of the information provided.

$$
<\text { Figure 4 >> }
$$

In addition to previous considerations, it is relevant to underline that interviewees particularly appreciated the structure of the model proposed, as well as its organization in categories. This is an important achievement, which was pointed out as major research gap by literature, as so far contributions on drivers on IS were less structured than those applied to specific single areas of IS, either with just macro-categories, e.g. (Kara et al., 2014; Sy, 2014), or without even a categorization, e.g. (Bocken et al., 2014; Gabzdylova et al., 2009). Second, as pointed out by the literature review, contributions on drivers to IS identified very few drivers with respect to those identified in single areas of IS, e.g. (Collins et al., 2007; Lloret, 2016), whilst the model proposed here has been particularly valued for its completeness and capacity to represent. Third, interviewees underlined the usefulness of the model as guideline for drivers they were hitherto not provided with and "would not be able to develop" as quality and HSE manager of Firm 9 said, thus providing firms with a new view on drivers to the adoption of ISMs. Moreover, the model was considered a helpful instrument for enhancing collaboration among different departments of the same firm. Indeed, reporting the opinion of HSE manager of Firm 2 "the model is a holistic one, and allows collaboration among different departments; the division in categories is very helpful, since categories are related to the diverse firm's department like commercial, financial, quality, safety and production".

The model for drivers, given the previous considerations, presents several aspects of novelty, moreover it can identify general drivers to sustainability, as well as evaluate drivers to specific measures in the different areas of IS, and the combined evaluation of different areas of IS allowed to 
identify in specific area drivers not identified before, e.g. dialogue and encouragement for EcoEff, and communities and partners' pressures for OHS.

The results of the preliminary validation of the model of mechanisms were positive too. In particular, all the mechanisms identified by the interviewees were previously identified in theory. Nevertheless, due to the small number of respondents, it was not possible to verify all the theoretical mechanisms, but the overlap obtained is particularly significant. All the twelve interviewees stated the model of mechanisms between drivers and barriers and between drivers was very useful and almost all of them stated it was easy to be used. The only hindrance underlined was the time needed for filling the matrix, since it contained quite a lot of information, but, at the same time, interviewees though it was necessary to properly analyse and understand all the possible mechanisms. This aspect was underlined for example by OHS manager of Firm 1, who stated: "I took me quite a long time to evaluate all the mechanisms but it is necessary for having a proper evaluation of mechanisms: going too fast I would have probably missed some of them".

Main mechanisms between drivers and barriers identified during the interviews can provide insights into those that may be the most relevant ones for firms, as reported in Table 4:

- Increase incomes can provide a higher availability of money, thus reducing the barrier of limited access to capital;

- Cost saving can as well contrast limited access to capital, being associated with an increased availability of money;

- Dialogue and encouragement can help improving communication;

- Training and education has a very important role since it is able to contrast several barriers related to employees, i.e. not trained/skilled employees, employees' awareness and incorrect behaviour;

- Commitment of employees can contrast both not involved employees and employees' lack of awareness;

- Organizational values and culture can have an effect on management commitment/awareness towards sustainability;

- Regulatory sanctions and taxes can overwhelm management commitment/awareness towards sustainability as well.

Examples of mechanisms between drivers and barriers are provided by OHS manager of Firm 1: " $a$ positive behaviour of the parent company tends to destroy non-safe approaches", and "commitment of the management provides the correct example and reduces the problem of resistance to change". $<$ Table 4>>

Main mechanisms between drivers identified during the interviews can provide insights into those that may be the most relevant ones for firms:

- Increase of market share and sales growth may lead to increasing incomes, cost saving and stimulate a greater efficiency in processes;

- New market opportunities can foster the adoption of technology innovation;

- Competitors' actions may encourage the firm in developing product innovation as well as technology innovation;

- Consumers' pressures can help in increasing the management commitment;

- Improvement of sustainability related performance may stimulate both management commitment and employees commitment;

- Quality related drivers can, as well, prompt management commitment.

An example of mechanism between drivers was provided by OHS assistant of Firm 2, who stated that "efficient and effective production system must be guaranteed to provide a compliant product and keep up with the market demand" since "competitiveness can be obtained minimizing costs", for which "technology innovation, optimal working conditions and motivation of the personnel are necessary". Table 5 and Table 6 report, respectively, mechanisms between enabler (external) and 
internal drivers, and enabler (internal) and simple drivers.

$$
\begin{aligned}
& <\text { Table 5 >> } \\
& <<\text { Table 6>> }
\end{aligned}
$$

The model of mechanisms resulted very helpful for increasing awareness, as underlined by HSE manager of Firm 5. In addition, OHS manager within Firm 1 stated "the model allows to fully explore all reasoning behind the decision-making process". Similarly, HSE manager of Firm 9 appreciated the completeness of the model and its ability to bringing out possible criticalities within the firm. In this way, as declared by OHS manager of Firm 6, and confirmed by OHS manager of Firm 1 as well as sustainability and quality manager of Firm 3 "the mechanisms matrices are able to immediately underline the criticalities and weakness, so that one is able to identify straightway what it is necessary to and strategic actions".

Moreover, interviewees particularly appreciated mechanisms between drivers and barriers, as emerged talking with sales manager of Firm 4, and HSE manager of both Firm 5 and Firm 7. In particular, plant manager of Firm 8 said: "mechanisms between drivers and barriers are very interesting, since barriers are the first thing that someone face when trying to adopt an ISM".

The model of mechanisms was thus able to properly address the research gaps identified after the literature review. In comparison with previous literature contributions, our model is able to enhance the knowledge and awareness of IDMs, as well as to provide them with a holistic and complete view on mechanisms, considering for the first time both mechanisms between drivers and barriers and mechanisms between drivers for IS. Indeed, the extant contributions describing the single mechanisms between drivers and barriers were focused only on EnEff (Cagno et al., 2017; Trianni et al., 2017a, 2016), thus not providing a complete view on the IS. Also regarding mechanisms between drivers, acknowledging we based our work on previous literature (Lozano, 2015), we broadened the research by theoretically modelling every single mechanism and considering also mechanisms between drivers and barriers, rather than only the ones between drivers.

\section{Conclusions}

In this study, we presented a novel framework of drivers for ISMs, including a model of drivers as well as a model of mechanisms between drivers and barriers, and between drivers. In our validation of the model, interviewees positively evaluated the capacity to represent the full set of drivers to IS with sufficient distinction between them and with the same level of detail. Moreover, they appreciated the capacity to point out hidden drivers, but also to offer a structured view on already identified drivers for the adoption of ISMs, with valuable information easily presented, thus enhancing their knowledge and awareness on IS drivers. Regarding the mechanisms, interviewees appreciated the usefulness of the novel approach, particularly for the mechanisms between drivers and barriers, thus understanding whether and to what extent a barrier can be overcome by a driver, but also the mechanisms between drivers, thus looking at whether a driver may act as an enabler for one or more other drivers.

Empirically evidence has shown that our novel framework provides several useful insights. First, it allows an enhanced knowledge of sustainability issues, thus pointing out also multiple perspectives between different internal stakeholders, so clarifying the extant opportunities to promote ISMs in their company. Second, it points out that a single driver could act on multiple barriers to the adoption of ISMs, thus showing important possible synergies by leveraging on a given driver. Third, it shows that external drivers may act directly onto barriers, reducing the resistance to the adoption of ISMs, but also as enablers on internal drivers, stimulating internal stakeholders to tackle existing internal barriers to ISMs adoption.

In conclusion, our framework may represent a valuable instrument to be adopted by IDMs, as it helps not only to better understand the most important drivers, but also to organize internal resources and 
develop appropriate implementation strategies for improved IS within an industrial company. Moreover, thanks to the distinction between external and internal drivers, companies could better understand the most effective drivers tackling existing barriers. Further, external stakeholders (e.g., technology suppliers or service providers) offering solutions for improved IS could benefit by taking this framework to assess the most effective ways to promote their solutions within a specific company, as the mechanisms between drivers and barriers (but also external drivers and internal drivers) do not depend just on the firm, but also on the specific ISM considered. Finally, policymakers focusing their activities on promoting IS, would take benefit by considering this framework to develop a more effective regulatory framework, thus more specifically designing incentives to encourage firms to adopt ISMs.

Unfortunately, considering the sample investigated, we could not interview multiple internal stakeholders in all firms, i.e. one for each area of IS, and for geographical constraints, we were able to conduct the validation of the model only in Italy. Another limitation can be represented by the study scope on specific areas of IS (OHS, EE, EnEff), thus neglecting implications related to possible remaining areas of sustainability in general terms.

To conclude, we would like to mark some further research avenues. From a theoretical perspective, the study could be complemented, on the one hand, by a framework able to relate each driver to the stakeholder(s) that may promote them, also considering the different steps of a decision-making process; on the other hand, by a framework for measuring the performance of companies with respect to IS, thus evaluating the relationships among barriers, drivers and level of performance reached with reference to the adoption of a specific ISM. Furthermore, it would be worth investigating how these relationships vary according to different perspectives of IDMs and when considering from both a single firm perspective and/or from a system context one, i.e. a supply chain or an industrial district. From an empirical perspective, it would be very interesting to investigate a larger sample of firms, differing with respect to e.g. country, size, sector, labour and capital intensity, energy intensity etc., in order to identify the main drivers, and similarities and differences in the drivers according to the different types of possible firms' clusters. This empirical knowledge could represent a valuable support for local and regional policy-makers, as well as other stakeholders (e.g. industrial associations and groupings), so to shape more effective policies for increased IS.

\section{References}

Abeelen, C., Harmsen, R., Worrell, E., 2013. Implementation of energy efficiency projects by Dutch industry. Energy Policy 63, 408-418. doi:10.1016/j.enpol.2013.09.048

Aflaki, S., Kleindorfer, P.R., De Miera Polvorinos, V.S., 2013. Finding and implementing energy efficiency projects in industrial facilities. Prod. Oper. Manag. 22, 503-517. doi:10.1111/j.19375956.2012.01377.x

AIDA, 2017. https://aida.bvdinfo.com/version-20171011/home. serv?product=AidaNeo

Altham, W., 2007. Benchmarking to trigger cleaner production in small businesses: drycleaning case study. J. Clean. Prod. 15, 798-813. doi:10.1016/j.jclepro.2006.07.005

Alves, J.L.S., Dumke De Medeiros, D., 2015. Eco-efficiency in micro-enterprises and small firms: a case study in the automotive services sector. J. Clean. Prod. 108, 595-602. doi:10.1016/j.jclepro.2015.07.063

Ambec, S., Lanoie, P., 2008. Does it pay to be green? A systematic overview. Acad. Manag. Perspect. 22, 45-62. doi:10.5465/AMP.2008.35590353

Anderson, S.T., Newell, R.G., 2004. Information programs for technology adoption: the case of energy-efficiency audits. Resour. Energy Econ. 26, 27-50. doi:10.1016/j.reseneeco.2003.07.001

Antonsson, A., Birgersdotter, L., Bornberger-Dankvardt, S., 2002. Small enterprises in Sweden in $\begin{array}{llll}\text { preventive health and } & \text { afety. }\end{array}$ https://gupea.ub.gu.se/bitstream/2077/4292/1/ah2002_01.pdf 
Apeaning, R.W., Thollander, P., 2013. Barriers to and driving forces for industrial energy efficiency improvements in African industries - a case study of Ghana's largest industrial area. J. Clean. Prod. 53, 204-213. doi:10.1016/j.jclepro.2013.04.003

Arevalo, J.A., Aravind, D., 2011. Corporate social responsibility practices in India: approach, drivers, and barriers. Corp. Gov. 11, 399-414. doi:10.1108/14720701111159244

Arruda, L.R., Lameira, V.D.J., Goncalves Quelhas, O.L., Pereira, F.N., 2013. Sustainability in the Brazilian heavy construction industry: an analysis of organizational practices. Sustainability 5, 4312-4328. doi:10.3390/su5104312

Arvai, J., Campbell-Arvai, V., Steel, P., 2012. Decision-making for sustainability: a systematic review of the body of knowledge. https://goo.gl/usniZ2

Azapagic, A., Perdan, S., 2000. Indicators of sustainable development for industry: a general framework. Trans IChemE 78, 243-261. doi:10.1205/095758200530763

Beckmann, M., Hielscher, S., Pies, I., 2014. Commitment strategies for sustainability: how business firms can transform trade-offs into win-win outcomes. Bus. Strateg. Environ. 23, 18-37. doi:10.1002/bse. 1758

Blok, V., Long, T.B., Gaziulusoy, A.I., Ciliz, N., Lozano, R., Huisingh, D., Csutora, M., Boks, C., 2015. From best practices to bridges for a more sustainable future: advances and challenges in the transition to global sustainable production and consumption. Introduction to the ERSCP stream of the Special volume. J. Clean. Prod. 108, 19-30. doi:10.1016/j.jclepro.2015.04.119

Bocken, N.M.P., Short, S.W., Rana, P., Evans, S., 2014. A literature and practice review to develop sustainable business model archetypes. J. Clean. Prod. 65, 42-56. doi:10.1016/j.jclepro.2013.11.039

Bossle, M.B., Dutra De Barcellos, M., Vieira, L.M., Sauvée, L., 2016. The drivers for adoption of eco-innovation. J. Clean. Prod. 113, 861-872. doi:10.1016/j.jclepro.2015.11.033

Brammer, S., Hoejmose, S., Marchant, K., 2012. Environmental management in SMEs in the UK: practices, pressures and perceived benefits. Bus. Strateg. Environ. 21, 423-434. doi:10.1002/bse.717

Brunke, J.C., Johansson, M., Thollander, P., 2014. Empirical investigation of barriers and drivers to the adoption of energy conservation measures, energy management practices and energy services in the Swedish iron and steel industry. J. Clean. Prod. 84, 509-525. doi:10.1016/j.jclepro.2014.04.078

Cagno, E., Masi, D., Leão, C.P., 2016. Drivers for OSH interventions in small and medium-sized enterprises. Int. J. Occup. Saf. Ergon. 22, 102-115. doi:10.1080/10803548.2015.1117351

Cagno, E., Micheli, G.J.L., Perotti, S., 2011. Identification of OHS-related factors and interactions among those and OHS performance in SMEs. Saf. Sci. 49, 216-225. doi:10.1016/j.ssci.2010.08.002

Cagno, E., Neri, A., Trianni, A., 2018. Broadening to sustainability the perspective of industrial decision-makers on the energy efficiency measures adoption: some empirical evidence. Energy Effic. doi:10.1007/s12053-018-9621-0

Cagno, E., Trianni, A., 2014. Evaluating the barriers to specific industrial energy efficiency measures: an exploratory study in small and medium-sized enterprises. J. Clean. Prod. 82, 70-83. doi:10.1016/j.jclepro.2014.06.057

Cagno, E., Trianni, A., 2013. Exploring drivers for energy efficiency within small- and medium-sized enterprises: first evidences from Italian manufacturing enterprises. Appl. Energy 104, 276-285. doi:10.1016/j.apenergy.2012.10.053

Cagno, E., Trianni, A., Abeelen, C., Worrell, E., Miggiano, F., 2015. Barriers and drivers for energy efficiency: different perspectives from an exploratory study in the Netherlands. Energy Convers. Manag. 102, 26-38. doi:10.1016/j.enconman.2015.04.018

Cagno, E., Trianni, A., Spallina, G., Marchesani, F., 2017. Erratum to: Drivers for energy efficiency and their effect on barriers: empirical evidence from Italian manufacturing enterprises. Energy Effic. 10, 871. doi:10.1007/s12053-016-9498-8 
Cagno, E., Worrell, E., Trianni, A., Pugliese, G., 2013. A novel approach for barriers to industrial energy efficiency. Renew. Sustain. Energy Rev. 19, 290-308. doi:10.1016/j.rser.2012.11.007

Chan, E.S.W., 2008. Barriers to EMS in the hotel industry. Int. J. Hosp. Manag. 27, 187-196. doi:10.1016/j.ijhm.2007.07.011

Charmondusit, K., Phatarachaisakul, S., Prasertpong, P., 2014. The quantitative eco-efficiency measurement for small and medium enterprise: a case study of wooden toy industry. Clean Technol. Environ. Policy 16, 935-945. doi:10.1007/s10098-013-0693-4

Cherniack, M., Lahiri, S., 2010. Barriers to implementation of workplace health interventions: an economic perspective. J. Occup. Environ. Med. 52, 934-942. doi:10.1097/JOM.0b013e3181f26e59

Collins, E., Lawrence, S., Pavlovich, K., Ryan, C., 2007. Business networks and the uptake of sustainability practices: the case of New Zealand. J. Clean. Prod. 15, 729-740. doi:10.1016/j.jclepro.2006.06.020

Collins, E., Roper, J., Lawrence, S., 2010. Sustainability practices: trends in New Zealand businesses. Bus. Strateg. Environ. 19, 479-494. doi:10.1002/bse.653

Cooremans, C., 2012. Energy-efficiency investments An interpretative perspective and energy management : doi:10.13140/2.1.4787.5529

Dagiliūtè, R., Juknys, R., 2012. Eco-efficiency: trends, goals and their implementation in Lithuania. J. Environ. Eng. Landsc. Manag. 20, 265-272. doi:10.3846/16486897.2012.661072

De Araujo, J.B., Gomes De Oliveira, J.F., 2012. Towards a balanced scoreboard for assessing manufacturing processes sustainability. Int. J. Bus. Perform. Manag. 13, 198. doi:10.1504/IJBPM.2012.046201

De Groot, H.L. f., Verhoef, E.T., Nijkamp, P., 2001. Energy saving by firms: decision-making, barriers and policies. Energy Econ. 23, 717-740. doi:10.1016/S0140-9883(01)00083-4

De Medeiros, J.F., Ribeiro, J.L.D., Cortimiglia, M.N., 2014. Success factors for environmentally sustainable product innovation: a systematic literature review. J. Clean. Prod. 65, 76-86. doi:10.1016/j.jclepro.2013.08.035

Del Río González, P., 2005. Analysing the factors influencing clean technology adoption: a study of the Spanish pulp and paper industry. Bus. Strateg. Environ. 14, 20-37. doi:10.1002/bse.426

Dicicco-Bloom, B., Crabtree, B.F., 2006. The qualitative research interview. Med. Educ. 40, 314-21. doi:10.1111/j.1365-2929.2006.02418.x

Dobes, V., 2013. New tool for promotion of energy management and cleaner production on no cure, no pay basis. J. Clean. Prod. 39, 255-264. doi:10.1016/j.jclepro.2012.08.007

Dyllick, T., Hockerts, K., 2002. Beyond the business case for corporate sustainability. Bus. Strateg. Environ. 11, 130-141. doi:10.1002/bse.323

EASHW, 2010. European Survey of Enterprises on New and Emerging Risks Man- aging Safety and Health at Work. European Agency for Safety and Health at Work. Retrieved from the WWW, December 2014: https://osha.europa.eu/en/ publications/reports/esener1_osh_management.

Eisenhardt, K.M., 1989. Building theories from case study research. Acad. Manag. J. 14, 532-550. doi:10.5465/AMR.1989.4308385

Elkington, J.,1998. Cannibals with forks: the triple bottomline of 21-st century business, Capstone

Ekins, P., 2005. Eco-efficiency: motives, drivers, and economic implications. J. Ind. Ecol. 9, 12-14. doi:10.1162/108819805775247981

ENWHP, 2001. Small, Healthy and Competitive. New strategies for improved heaklth in small and medium-sized enterprises. http://www.enwhp.org/fileadmin/downloads/criteria.pdf

European Union, 2003. Commission Recommendation of 6 May 2003 concerning the definition of micro, small and medium-sized enterprises.

Eurostat, 2016. Manufacturing Statistics. Retrieved from the WWW, March 2017: http://ec.europa.eu/eurostat/statistics-explained/index.php/Manufacturing _ statistics__NACE_Rev._2.

Evans, S., Bergendahl, M., Gregory, M., Ryan, C., 2009. Towards a sustainable industrial System. 
The Institute for Manufacturing, Cardiff. Retrieved from the WWW, March 2017: http://orbit.dtu.dk/fedora/objects/orbit:81752/ datastreams/file_4085316/content.

Fennema, O., 2000. Industrial sustainability: Lifting the siege on earth and our descendents. Food Technol. 54.

Fernández-Viñé, M.B., Gómez-Navarro, T., Capuz-Rizo, S.F., 2010. Eco-efficiency in the SMEs of Venezuela. Current status and future perspectives. J. Clean. Prod. 18, 736-746. doi:10.1016/j.jclepro.2009.12.005

Fernández-Viñé, M.B., Gómez-Navarro, T., Capuz-Rizo, S.F., 2013. Assessment of the public administration tools for the improvement of the eco-efficiency of Small and Medium Sized Enterprises. J. Clean. Prod. 47, 265-273. doi:10.1016/j.jclepro.2012.08.026

Fleiter, T., Hirzel, S., Worrell, E., 2012. The characteristics of energy-efficiency measures - A neglected dimension. Energy Policy 51, 502-513. doi:10.1016/j.enpol.2012.08.054

Fonseca, L.M., 2015. Strategic drivers for implementing sustainability programs in portuguese organizations-let's listen to aristotle: from triple to quadruple bottom line. Sustain. (United States) 8, 136-142. doi:10.1089/SUS.2015.29004

Frankental, P., 2001. Corporate social responsibility - a PR invention? Corp. Commun. An Int. J. 6, 18-23. doi:10.1108/13563280110381170

Frini, A., Benamor, S., 2017. Making decisions in a sustainable development context: a state-of-theart survey and proposal of a multi-period single synthesizing criterion approach. Comput. Econ. 1-45. doi:10.1007/s10614-017-9677-5

Gabzdylova, B., Raffensperger, J.F., Castka, P., 2009. Sustainability in the New Zealand wine industry: drivers, stakeholders and practices. J. Clean. Prod. 17, 992-998. doi:10.1016/j.jclepro.2009.02.015

Gangwar, M., Goodrum, P.M., 2005. The effect of time on safety incentive programs in the US construction industry. Constr. Manag. Econ. 23, 851-859. doi:10.1080/01446190500184527

Garetti, M., Taisch, M., 2012. Sustainable manufacturing: trends and research challenges. Prod. Plan. Control 23, 83-104. doi:10.1080/09537287.2011.591619

Ghazilla, R.A.R., Sakundarini, N., Abdul-Rashid, S.H., Ayub, N.S., Olugu, E.U., Musa, S.N., 2015. Drivers and barriers analysis for green manufacturing practices in Malaysian SMEs: a preliminary findings. Procedia CIRP 26, 658-663. doi:10.1016/j.procir.2015.02.085

Gibson, R.B., 2006. Beyond the pillars: sustainability assessment as a framework for effective integration of social, economic and ecological considerations in significant decision-making. J. Environ. Assess. Policy Manag. 8, 259-280. doi:10.1142/S1464333206002517

Gimenez, C., Sierra, V., Rodon, J., 2012. Sustainable operations: their impact on the triple bottom line. Int. J. Prod. Econ. 140, 149-159. doi:10.1016/j.ijpe.2012.01.035

Glavič, P., Lukman, R., 2007. Review of sustainability terms and their definitions. J. Clean. Prod. 15, 1875-1885. doi:10.1016/j.jclepro.2006.12.006

Gong, M., Simpson, A., Koh, L., Tan, K.H., 2016. Inside out: the interrelationships of sustainable performance metrics and its effect on business decision making: theory and practice. Resour. Conserv. Recycl. In press. doi:10.1016/j.resconrec.2016.11.001

Govindan, K., Diabat, A., Madan Shankar, K., 2015. Analyzing the drivers of green manufacturing with fuzzy approach. J. Clean. Prod. 96, 182-193. doi:10.1016/j.jclepro.2014.02.054

Gutowski, T., Murphy, C., Allen, D., Bauer, D., Bras, B., Piwonka, T., Sheng, P., Sutherland, J., Thurston, D., Wolff, E., 2005. Environmentally benign manufacturing: observations from Japan, Europe and the United States. J. Clean. Prod. 13, 1-17. doi:10.1016/j.jclepro.2003.10.004

Haffar, M., Searcy, C., 2017. Classification of trade-offs encountered in the practice of corporate sustainability. J. Bus. Ethics 140, 1-28. doi:10.1007/s10551-015-2678-1

Hale, A.R., Guldenmund, F.W., Van Loenhout, P.L.C.H., Oh, J.I.H., 2010. Evaluating safety management and culture interventions to improve safety: effective intervention strategies. Saf. Sci. 48, 1026-1035. doi:10.1016/j.ssci.2009.05.006

Hasanbeigi, A., Menke, C., Du Pont, P., 2010. Barriers to energy efficiency improvement and 
decision-making behavior in Thai industry. Energy Effic. 3, 33-52. doi:10.1007/s12053-0099056-8

Hasle, P., Limborg, H.J., 2006. A review of the literature on preventive occupational health and safety activities in small enterprises. Ind. Health 44, 6-12. doi:10.2486/indhealth.44.6

Heckathorn, D.D., Cameron, C.J., 2017. Network sampling: from snowball and multiplicity to respondent-driven sampling. Annu. Rev. Sociol. 43, 101-119. doi:10.1146/annurev-soc-060116

Henri, J.F., Journeault, M., 2009. Eco-efficiency and organizational practices: an exploratory study of manufacturing firms. Environ. Plan. C Gov. Policy 27, 894-921. doi:10.1068/c0827

Hillebrand, B., Kok, R.A.W., Biemans, W.G., 2001. Theory-testing using case studies. Ind. Mark. Manag. 30, 651-657. doi:10.1016/S0019-8501(00)00115-2

Hojnik, J., Ruzzier, M., 2016. What drives eco-innovation? A review of an emerging literature. Environ. Innov. Soc. Transitions 19, 31-41. doi:10.1016/j.eist.2015.09.006

INAIL, 2014. Banche Dati [WWW Document]. URL http://bancadaticsa.inail.it/bancadaticsa/login.asp (accessed 10.31.14).

Jochem, E., Gruber, E., 2007. Local learning-networks on energy efficiency in industry - Successful initiative in Germany. Appl. Energy 84, 806-816. doi:10.1016/j.apenergy.2007.01.011

Johansson, M.T., Thollander, P., 2018. A review of barriers to and driving forces for improved energy efficiency in Swedish industry - Recommendations for successful in-house energy management. Renew. Sustain. Energy Rev. 82, 618-628. doi:10.1016/j.rser.2017.09.052

Kara, S., Suphunnika, I., Kayis, B., 2014. Sustainable product development in practice: an international survey. J. Manuf. Technol. Manag. 25, 848-872. doi:http://dx.doi.org/10.1108/09564230910978511

Kleine, A., Von Hauff, M., 2009. Sustainability-driven implementation of corporate social responsibility: application of the integrative sustainability triangle. J. Bus. Ethics 85, 517-533. doi:10.1007/s10551-009-0212-z

Klewitz, J., Hansen, E.G., 2014. Sustainability-oriented innovation of SMEs: a systematic review. J. Clean. Prod. 65, 57-75. doi:10.1016/j.jclepro.2013.07.017

Kogi, K., 2006. Advances in participatory occupational health aimed at good practices in small enterprises and the informal sector. Ind. Health 44, 31-34. doi:10.2486/indhealth.44.31

Koho, M., Torvinen, S., Romiguer, A.T., 2011. Objectives, enablers and challenges of sustainable development and sustainable manufacturing. Assem. Manuf. 1-6. doi:10.1109/ISAM.2011.5942343

Kostka, G., Moslener, U., Andreas, J., 2013. Barriers to increasing energy efficiency: evidence from small-and medium-sized enterprises in China. J. Clean. Prod. 57, 59-68. doi:10.1016/j.jclepro.2013.06.025

Küçüksayraç, E., 2015. Design for sustainability in companies: strategies, drivers and needs of Turkey's best performing businesses. J. Clean. Prod. 106, 455-465. doi:10.1016/j.jclepro.2015.01.061

Lamm, F., 1999. Occupational health \& safety in Australian small business : what can be done to reduce the lack of awareness and raise the level of compliance in Australian small business? Industrial Relations Research Centre, University of New South Wales, Sidney.

Langley, A., Mintzberg, H., Pitcher, P., Posada, E., Saint-Macary, J., 1995. Opening up decision making: the view from the black stool. Organ. Sci. 6, 260-279. doi:10.1287/orsc.6.3.260

Lee, K., 2015. Drivers and barriers to energy efficiency management for sustainable development. Sustain. Dev. 25, 16-25. doi:10.1002/sd.1567

Lijo, J., Gopalakrishnan, N., 2015. Converging sustainability definitions: industry independent dimensions. World J. Sci. Technol. Sustaiable Dev. 12, 206-232. doi:10.1108WJSTSD-042015-0017

Lloret, A., 2016. Modeling corporate sustainability strategy. J. Bus. Res. 69, 418-425. doi:10.1016/j.jbusres.2015.06.047

Lozano, R., 2015. A holistic perspective on corporate sustainability drivers. Corp. Soc. Responsib. 
Environ. Manag. 22, 32-44. doi:10.1002/csr.1325

Lozano, R., Carpenter, A., Huisingh, D., 2015. A review of "theories of the firm" and their contributions to Corporate Sustainability. J. Clean. Prod. 106, 430-442. doi:10.1016/j.jclepro.2014.05.007

Martín-Peña, M.L., Díaz-Garrido, E., Sánchez-López, J.M., 2014. Analysis of benefits and difficulties associated with firms' Environmental Management Systems: the case of the Spanish automotive industry. J. Clean. Prod. 70, 220-230. doi:10.1016/j.jclepro.2014.01.085

Masi, D., Cagno, E., Micheli, G.J.L., 2014. Developing, implementing and evaluating OSH interventions in SMEs: an exploratory study. Int. J. Occup. Saf. Ergon. 20, 1-10. doi:10.1080/10803548.2014.11077059

Masurel, E., 2007. Why SMEs invest in environmental measures: sustainability evidence from small and medium-sized printing firms. Bus. Strateg. Environ. 16, 190-201. doi:10.1002/bse.478

Mellor, N., Mackay, C., Packham, C., Jones, R., Palferman, D., Webster, S., Kelly, P., 2011. "Management Standards" and work-related stress in Great Britain: progress on their implementation. Saf. Sci. 49, 1040-1046. doi:10.1016/j.ssci.2011.01.010

Merli, R., Preziosi, M., Massa, I., 2015. Social values and sustainability: a survey on drivers, barriers and benefits of SA8000 certification in Italian firms. Sustain. 7, 4120-4130. doi:10.3390/su7044120

Miller, P., Haslam, C., 2009. Why employers spend money on employee health: interviews with occupational health and safety professionals from British Industry. Saf. Sci. 47, 163-169. doi:10.1016/j.ssci.2008.04.001

Mittal, V.K., Egede, P., Herrmann, C., Sangwan, K.S., 2013. Comparison of drivers and barriers to green manufacturing : a case of India and Germany, in: Re-Engineering Manufacturing for Sustainability. Springer Singapore, pp. 723-728. doi:10.1007/978-981-4451-48-2_118

Mittal, V.K., Sangwan, K.S., 2015. Ranking of drivers for green manufacturing implementation using fuzzy technique for order of preference by similarity to ideal solution method. J. Multi-Criteria Decis. Anal. 22, 119-130. doi:10.1002/mcda

Morioka, S.N., Carvalho, M.M., 2014. Measuring sustainability in practice: exploring the inclusion of sustainability into corporate performance systems in Brazilian case studies. J. Clean. Prod. 136, 123-133. doi:10.1016/j.jclepro.2016.01.103

Murillo-Luna, J.L., Garcés-Ayerbe, C., Rivera-Torres, P., 2011. Barriers to the adoption of proactive environmental strategies. J. Clean. Prod. 19, 1417-1425. doi:10.1016/j.jclepro.2011.05.005

Murmura, F., Liberatore, L., Bravi, L., Casolani, N., 2018. Evaluation of Italian companies' perception about ISO 14001 and eco management and audit scheme III: motivations, benefits and barriers. J. Clean. Prod. 174, 691-700. doi:10.1016/j.jclepro.2017.10.337

Nicolăescu, E., Alpopi, C., Zaharia, C., 2015. Measuring corporate sustainability performance. Sustainability 7, 851-865. doi:10.3390/su7010851

Norsiah, H., Mohd Razali, M., Zuhriah, E., 2015. The impact of sustainable manufacturing practices and innovation performance on economic sustainability. Procedia CIRP 26, 190-195. doi:10.1016/j.procir.2014.07.167

Okazaki, T., Yamaguchi, M., 2011. Accelerating the transfer and diffusion of energy saving technologies steel sector experience-Lessons learned. Energy Policy 39, 1296-1304. doi:10.1016/j.enpol.2010.12.001

Osagie, E.R., Wesselink, R., Blok, V., Lans, T., Mulder, M., 2016. Individual competencies for Corporate Social Responsibility: a literature and practice perspective. J. Bus. Ethics 135, 233252. doi:10.1007/s10551-014-2469-0

Pagell, M., Gobeli, D., 2009. How plant managers' experiences and attitudes toward sustainability relate to operational performance. Prod. Oper. Manag. 18, 278-299. doi:10.1111/j.19375956.2009.01050.x

Pagell, M., Wu, Z.H., 2009. Building a more complete theory of sustainable supply chain management using case studies of 10 exemplars. J. Supply Chain Manag. 45, 37-56. 
doi:10.1111/j.1745-493X.2009.03162.X

Paramanathan, S., Farrukh, C., Phaal, R., Probert, D., 2004. Implementing industrial sustainability : the research issues in technology management. R\&D Manag. 34, 527-537. doi:10.1111/j.14679310.2004.00360.x

Patton, M.Q., 1990. Qualitative Evaluation Methods. SAGE, Beverly Hills.

Pehlken, A., Decker, A., Kottowski, C., Kirchner, A., Thoben, K.D., 2015. Energy efficiency in processing of natural raw materials under consideration of uncertainties. J. Clean. Prod. 106, 351-363. doi:10.1016/j.jclepro.2014.08.076

Pransky, G., Snyder, T., Dembe, A., Himmelstein, J.A.Y., 1999. Under-reporting of work-related disorders in the workplace : a case study and review of the literature. Ergonomics 42, 171-182. doi:10.1080/001401399185874

Rademaekers, K., Zaki, S.S., Smith, M., 2011. Sustainable Industry: Going for Growth \& Resource Efficiency. Retrieved from the WWW, March 2016: http://www.symbiosis.dk/en/content/sustainable-industry-going-growth-resource- efficiency.

Razali, A.R., Tahir, I.M., 2011. Review of the Literature on Enterprise Risk Management. Bus. Manag. Dynamincs 1, 8-16.

Ren, T., 2009. Barriers and drivers for process innovation in the petrochemical industry: a case study. J. Eng. Technol. Manag. 26, 285-304. doi:10.1016/j.jengtecman.2009.10.004

Rohdin, P., Thollander, P., 2006. Barriers to and driving forces for energy efficiency in the nonenergy intensive manufacturing industry in Sweden. Energy 31, 1836-1844. doi:10.1016/j.energy.2005.10.010

Rohdin, P., Thollander, P., Solding, P., 2007. Barriers to and drivers for energy efficiency in the Swedish foundry industry. Energy Policy 35, 672-677. doi:10.1016/j.enpol.2006.01.010

Roy, M., Parent, R., Desmarais, L., 2003. Knowledge networking: a strategy to improve workplace health \& safety knowledge transfer. Electron. J. Knowl. Manag. 1, 159-166.

Saksvik, P.Ø., Torvatn, H., Nytrø, K., 2003. Systematic occupational health and safety work in Norway: a decade of implementation. Saf. Sci. 41, 721-738. doi:10.1016/S09257535(02)00020-6

Salzmann, O., Ionescu-Somers, A.M., Steger, U., 2005. The business case for corporate sustainability: literature review and research options. Eur. Manag. J. 23, 27-36. doi:10.1016/j.emj.2004.12.007

Santini, C., Cavicchi, A., Casini, L., 2013. Sustainability in the wine industry: key questions and research trends. Agric. Food Econ. 1, 9. doi:10.1186/2193-7532-1-9

Santolaria, M., Oliver-Sol, J., Gasol, C.M., Morales-Pinzon, T., Rieradevall, J., 2011. Eco-design in innovation driven companies: perception, predictions and the main drivers of integration. the Spanish example. J. Clean. Prod. 19, 1315-1323. doi:10.1016/j.jclepro.2011.03.009

Santos, G., Murmura, F., Bravi, L., 2017. SA 8000 as a tool for a sustainable development strategy. Corp. Soc. Responsib. Environ. Manag. doi:10.1002/csr.1442

Sarkis, J., Gonzalez-Torre, P., Adenso-Diaz, B., 2010. Stakeholder pressure and the adoption of environmental practices: the mediating effect of training. J. Oper. Manag. 28, 163-176. doi:10.1016/j.jom.2009.10.001

Sathitbun-anan, S., Bundit, F., Barz, M., Sajjakulnukit, B., Pathumsawad, S., Fungtammasan, B., 2015. An analysis of the cost-effectiveness of energy efficiency measures and factors affecting their implementation: a case study of Thai sugar industry. Energy Effic. 8, 141-153. doi:10.1007/s12053-014-9281-7

Schleich, J., 2009. Barriers to energy efficiency: a comparison across the German commercial and services sector. Ecol. Econ. 68, 2150-2159. doi:10.1016/j.ecolecon.2009.02.008

Schrettle, S., Hinz, A., Scherrer-Rathje, M., Friedli, T., 2014. Turning sustainability into action: explaining firms' sustainability efforts and their impact on firm performance. Int. J. Prod. Econ. 147, 73-84. doi:10.1016/j.ijpe.2013.02.030

Seuring, S., 2013. A review of modeling approaches for sustainable supply chain management. Decis. 
Support Syst. 54, 1513-1520. doi:10.1016/j.dss.2012.05.053

Shi, H., Peng, S.Z., Liu, Y., Zhong, P., 2008. Barriers to the implementation of cleaner production in Chinese SMEs: government, industry and expert stakeholders' perspectives. J. Clean. Prod. 16, 842-852. doi:10.1016/j.jclepro.2007.05.002

Silva Lopes, A.D., Delai, I., De Castro, S.A.M., Roberto, A., 2013. Quality tools applied to cleaner production programs: a first approach toward a new methodology. J. Clean. Prod. 47, 174-187. doi:10.1016/j.jclepro.2012.10.026

Sims, R.H., 2008. Hazard abatement as a function of firm size - the effects of internal firm characteristics and external incentives. Doctoral Dissertation, Santa Monica, USA: Pardee Rand Graduate School.

Skolarus, T.A., Lehmann, T., Tabak, R.G., Harris, J., Lecy, J., Sales, A.E., 2017. Assessing citation networks for dissemination and implementation research frameworks. Implement. Sci. 12. doi:10.1186/s13012-017-0628-2

Smith, M.J., Carayon, P., 2009. Using the 'Balance model' for occupational safety and health promotion. In: Ergonomics and Health Aspects of Work with Computers. Springer, Verlag, Berlin, Heidelberg, pp. 105e114. http://dx.doi.org/10.1007/978- 3-642-02731-4_13.

Stuart, I., Mccutcheon, D., Handfield, R., Mclachlin, R., Samson, D., 2002. Effective case research in operations management: a process perspective. J. Oper. Manag. 20, 419-433. doi:10.1016/S0272-6963(02)00022-0

Sudhakara Reddy, B., Assenza, G.B., Assenza, D., Hasselmann, F., 2014. Erratum: Barriers and drivers to energy efficiency - A new taxonomical approach (Energy Conversion and Management (2013) 74 (403-416)). Energy Convers. Manag. 86, 1193. doi:10.1016/j.enconman.2014.06.077

Suriyankietkaew, S., Avery, G., 2016. Sustainable leadership practices driving financial performance: empirical evidence from Thai SMEs. Sustainability 8, 327. doi:10.3390/su8040327

Sy, M.V.U., 2014. Drivers of corporate social responsibility leading to sustainable development. Ind. Eng. Manag. Syst. 13, 342-355. doi:10.7232/iems.2014.13.3.342

Tait, R., Walker, D., 2000. Motivating the workforce: the value of external health and safety awards. J. Safety Res. 31, 243-251. doi:10.1016/S0022-4375(00)00043-8

Tanzil, D., Beloff, B.R., 2006. Assessing impacts: overview on sustainability indicators and metrics. Environ. Qual. Manag. 15, 41-56. doi:10.1002/tqem.20101

Thollander, P., Backlund, S., Trianni, A., Cagno, E., 2013. Beyond barriers - A case study on driving forces for improved energy efficiency in the foundry industries in Finland, France, Germany, Italy ,. Appl. Energy 111, 636-643. doi:10.1016/j.apenergy.2013.05.036

Thollander, P., Danestig, M., Rohdin, P., 2007. Energy policies for increased industrial energy efficiency: evaluation of a local energy programme for manufacturing SMEs. Energy Policy 35, 5774-5783. doi:10.1016/j.enpol.2007.06.013

Thollander, P., Ottosson, M., 2008. An energy efficient Swedish pulp and paper industry - exploring barriers to and driving forces for cost-effective energy efficiency investments. Energy Effic. 1, 21-34. doi:10.1007/s12053-007-9001-7

Thollander, P., Palm, J., 2012. Efficiency in industrial energy systems: an interdisciplinary perspective on barriers, energy audits, energy management, policies, and programs. Springer, London.

Tompa, E., Dolinschi, R., Oliveira, C. De, Irvin, E., 2009. A systematic review of occupational health economic analyses. J. Occup. Environ. Med. 51, 1004-1023. doi:10.1097/JOM.0b013e3181b34f60

Tonelli, F., Evans, S., Taticchi, P., 2013. Industrial sustainability : challenges, perspectives, actions. Int. J. Bus. Inov. Res. 7, 143-163. doi:10.1504/IJBIR.2013.052576

Trianni, A., Cagno, E., Farné, S., 2016. Barriers, drivers and decision-making process for industrial energy efficiency: a broad study among manufacturing small and medium-sized enterprises. Appl. Energy 162, 1537-1551. doi:10.1016/j.apenergy.2015.02.078 
Trianni, A., Cagno, E., Marchesani, F., Spallina, G., 2017a. Classification of drivers for industrial energy efficiency and their effect on the barriers affecting the investment decision-making process. Energy Effic. 10, 199-215. doi:10.1007/s12053-016-9455-6

Trianni, A., Cagno, E., Neri, A., 2017b. Modelling barriers to the adoption of industrial sustainability measures. J. Clean. Prod. 168, 1482-1504. doi:10.1016/j.jclepro.2017.07.244

Trianni, A., Cagno, E., Worrell, E., Pugliese, G., 2013. Empirical investigation of energy efficiency barriers in Italian manufacturing SMEs. Energy 49, 444-458. doi:10.1016/j.energy.2012.10.012

Van Berkel, R., 2007. Eco-efficiency in primary metals production: context, perspectives and methods. Resour. Conserv. Recycl. 51, 511-540. doi:10.1016/j.resconrec.2007.03.007

Van Der Byl, C.A., Slawinski, N., 2015. Embracing tensions in corporate sustainability: a review of research from win-wins and trade-offs to paradoxes and beyond. Organ. Environ. 28, 54-79. doi:10.1177/1086026615575047

Van Hemel, C., Cramer, J., 2002. Barriers and stimuli for ecodesign in SMEs. J. Clean. Prod. 10, 439-453. doi:10.1016/S0959-6526(02)00013-6

Van Marrewijk, M., 2003. Concepts and definitions of CSR and corporate sustainability: between agency and communion. J. Bus. Ethics 44, 95-105. doi:10.2307/25075020

Vecchio-Sadus, A.M., 2007. Enhancing safety sulture through effective communication. Saf. Sci. Monit. 11.

Vecchio-Sadus, A.M., Griffiths, S., 2004. Marketing strategies for enhancing safety culture. Saf. Sci. 42, 601-619. doi:10.1016/j.ssci.2003.11.001

Venmans, F., 2014. Triggers and barriers to energy efficiency measures in the ceramic, cement and lime sectors. J. Clean. Prod. 69, 133-142. doi:10.1016/j.jclepro.2014.01.076

Vermeulen, W.J. V, Witjes, S., 2016. On addressing the dual and embedded nature of business and the route towards corporate sustainability. J. Clean. Prod. 112, 2822-2832. doi:10.1016/j.jclepro.2015.09.132

Voss, C., Tsikriktsis, N., Frohlich, M., 2002. Case research in operations management. Int. J. Oper. Prod. Manag. 22, 195-219. doi:10.1108/01443570210414329

Walker, D., Tait, R., 2004. Health and safety management in small enterprises: an effective low cost approach. Saf. Sci. 42, 69-83. doi:10.1016/S0925-7535(02)00068-1

WBCSD, UNEP, 1998. Cleaner Production and Eco-efficiency Complementary Ap- proaches to Sustainable Development. Retrieved from the WWW, July 2017: http://gcpcenvis.nic.in/PDF/eco\%20effiency\%20and\%20CP.pdf.

Weidema, B., 2006. The integration of economic and social aspects in life cycle impact assessment. Int. J. Life Cycle Assess. 11, 89-96. doi:10.1065/lca2006.04.016

Whysall, Z., Haslam, C., Haslam, R., 2006. Implementing health and safety interventions in the workplace: an exploratory study. Int. J. Ind. Ergon. 36, 809-818. doi:10.1016/j.ergon.2006.06.007

Wohlin, C., 2014. Guidelines for snowballing in systematic literature studies and a replication in software engineering, in: Proceedings of the 18th International Conference on Evaluation and Assessment in Software Engineering - EASE '14. pp. 1-10. doi:10.1145/2601248.2601268

Yin, R.K., 2009. Case Study Research Design and Methods, 4th ed. SAGE, Thousand Oaks.

Zhang, B., Bi, J., Liu, B., 2009. Drivers and barriers to engage enterprises in environmental management initiatives in Suzhou Industrial Park, China. Front. Environ. Sci. Eng. China 3, 210-220. doi:10.1007/s11783-009-0014-7 


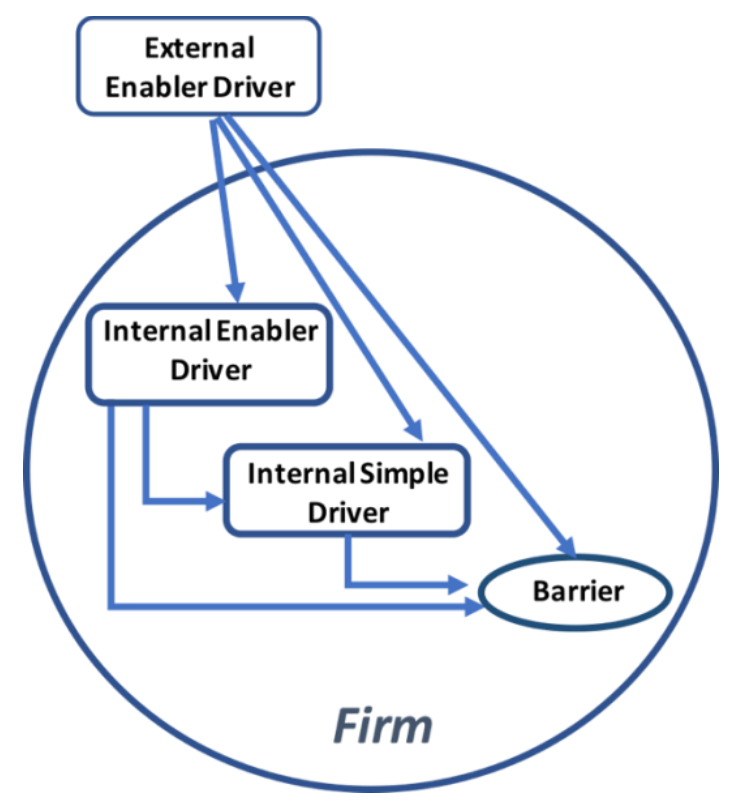

Figure 1. Mechanisms between drivers and barriers and between drivers. An external driver may impact directly on a barrier and/or may boost the impact of an internal driver on a barrier, thus acting as an enabler. A set of the internal drivers may impact directly on a barrier and/or may boost the impact of another internal drivers on a barrier, thus acting as enablers. Another set of internal drivers may only impact on barriers, thus acting as simple drivers. 


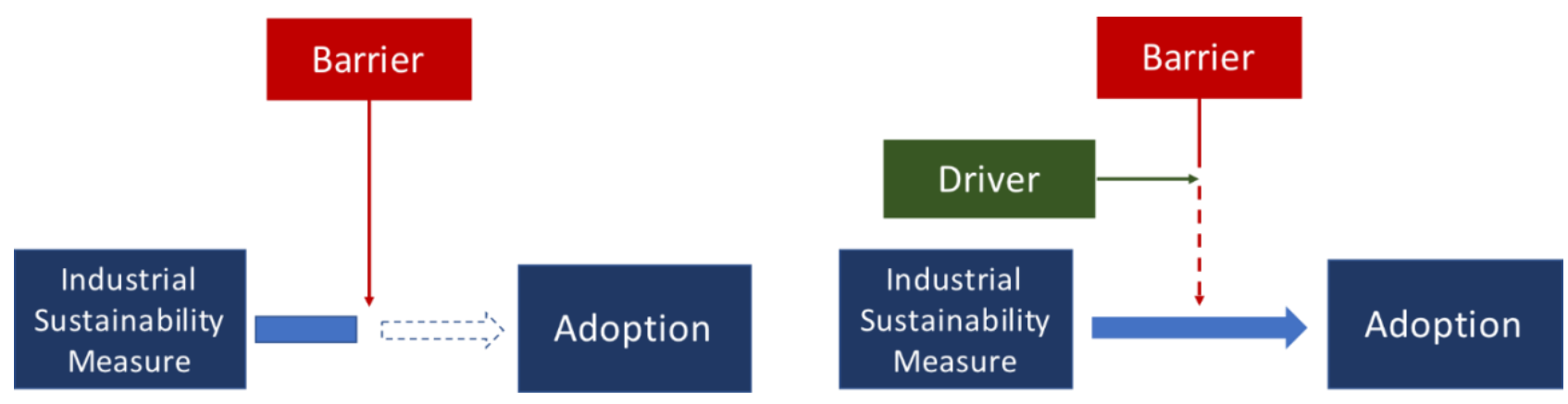

Figure 2. Mechanism between drivers and barriers. The adoption of an ISM can be prevented by the presence of a barrier. A specific driver may tackle the specific barrier, reducing or eliminating the effect of the barrier, so that the adoption of the ISM in less hindered or not hindered anymore. 


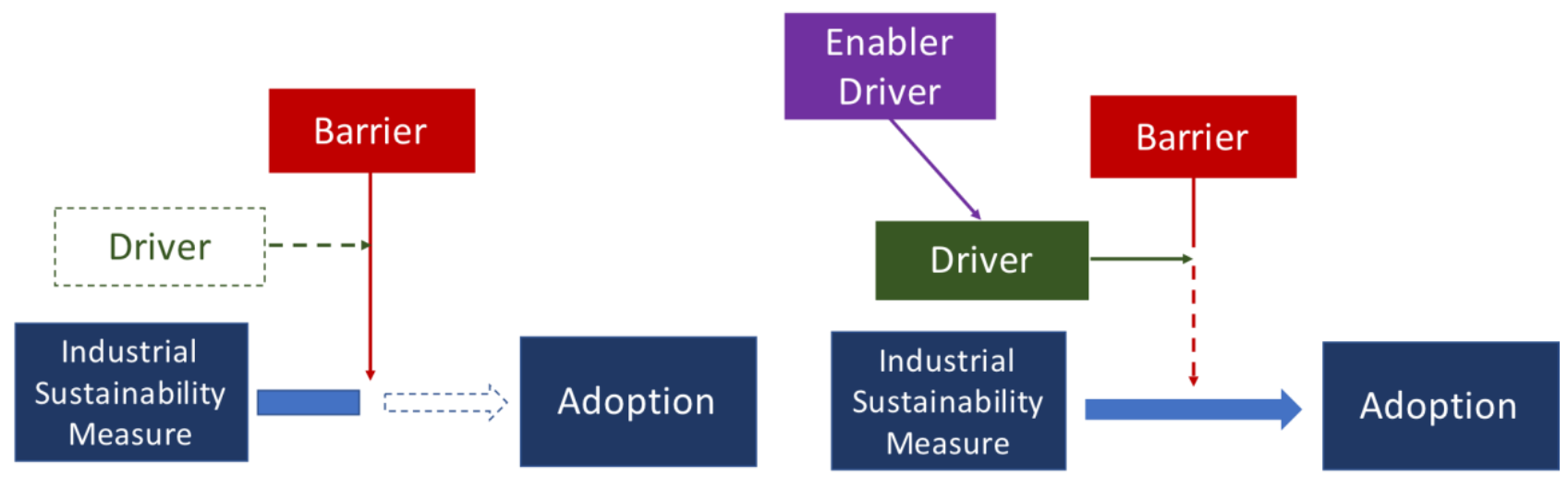

Figure 3. Mechanism between different drivers. The adoption of an ISM could be foster by the existent of a specific driver. Nevertheless, it may happen that this driver is not able by itself to promote the adoption of the ISM. An enabler driver may activate this driver, making possible to it to foster the adoption of the ISM. 


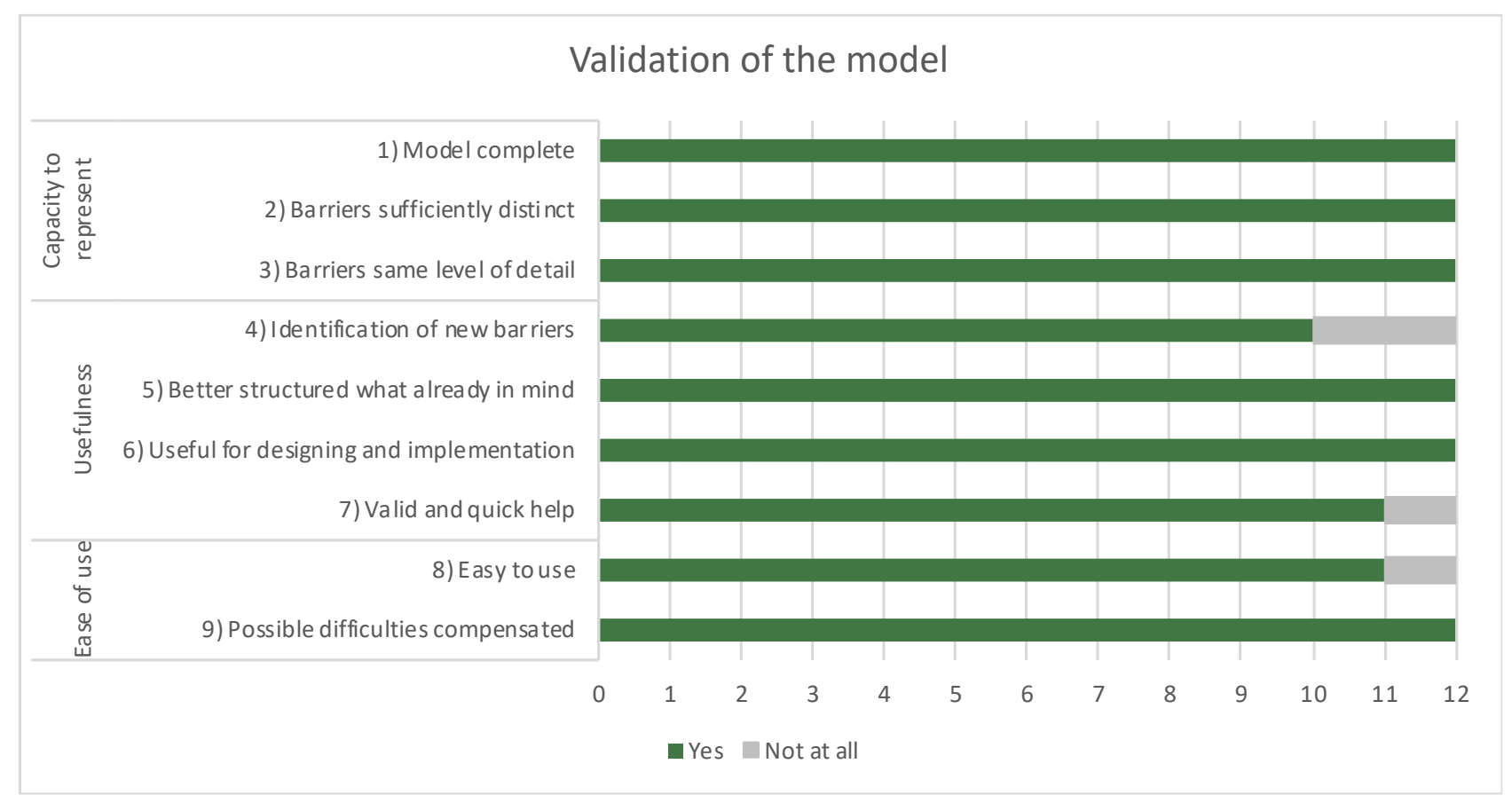

Figure 4. Results of the validation of the model of drivers. 
Table 1. The model of barriers to industrial sustainability. Source: Trianni et al. (2017b). For each barrier, a definition is provided.

\begin{tabular}{|c|c|c|}
\hline Category & Barrier & Definition \\
\hline \multirow{7}{*}{ Organization } & Lack of time & The firm does not have enough time for the implementation of the intervention \\
\hline & Lack of staff & The firm does not have enough staff for the implementation of the intervention \\
\hline & $\begin{array}{l}\text { Resistance to change/ } \\
\text { Inertia }\end{array}$ & $\begin{array}{l}\text { The organization can be against the change because it leads to a modification in ways of } \\
\text { working and in habits }\end{array}$ \\
\hline & Attitude/Other priorities & $\begin{array}{l}\text { The culture and the values of the firm inhibit the implementation of the interventions. } \\
\text { Moreover, the decision making might be focused almost exclusively on core the business } \\
\text { activity, thereby focusing mainly on productivity-related interventions. }\end{array}$ \\
\hline & Communication & $\begin{array}{l}\text { There is a lack of communication or inadequacy of communication between management } \\
\text { and workers or between the workers themselves }\end{array}$ \\
\hline & Workplace and task & $\begin{array}{l}\text { Not considering the workplace (analysis of the workplace, such as hazard exposures) and } \\
\text { the tasks (design, pace, repetition, pressure and psychosocial issues) during the } \\
\text { implementation of an intervention may have inhibitory consequences }\end{array}$ \\
\hline & Organizational system & $\begin{array}{l}\text { The firm is a social system influenced by goals, routines, and the organizational structure } \\
\text { and is dominated by the decision making. There are several factors related to the } \\
\text { company's structure that can hinder interventions. }\end{array}$ \\
\hline \multirow[b]{2}{*}{$\begin{array}{l}\text { Management } \\
\text { behaviour }\end{array}$} & Commitment/ Awareness & The manager has no awareness and/or commitment. \\
\hline & Expertise & $\begin{array}{l}\text { The manager lacks adequate management skills with respect to the issue or has limited } \\
\text { expertise. }\end{array}$ \\
\hline \multirow{4}{*}{$\begin{array}{l}\text { Workers } \\
\text { behaviour }\end{array}$} & Not trained/skilled & $\begin{array}{l}\text { A lack of adequate skill or training of the personnel, with respect to a specific intervention } \\
\text { area, can hinder the implementation of the intervention. }\end{array}$ \\
\hline & Awareness & $\begin{array}{l}\text { The staff lacks awareness on the issue and ignores it, which are criticalities of the firm } \\
\text { with respect to the issue. }\end{array}$ \\
\hline & Involvement & $\begin{array}{l}\text { Employees not involved are not given a fair opportunity to take active part in the } \\
\text { decision-making and realization process. }\end{array}$ \\
\hline & Incorrect behaviour & $\begin{array}{l}\text { The adoption of wrong behaviours by the personnel can hinder the implementation of } \\
\text { sustainability interventions in cases in which an active participation of the personnel is } \\
\text { required }\end{array}$ \\
\hline \multirow{2}{*}{ Information } & Lack of information & $\begin{array}{l}\text { There is a lack of information or inadequacy of the information owned by the firm } \\
\text { regarding all the aspects related to intervention implementation. }\end{array}$ \\
\hline & $\begin{array}{l}\text { Trustworthiness of } \\
\text { information sources }\end{array}$ & $\begin{array}{l}\text { There are problems with the trustworthiness of the information sources, and the sources } \\
\text { are not adequate. }\end{array}$ \\
\hline $\begin{array}{l}\text { Technology/ } \\
\text { Service }\end{array}$ & Lock in & The solution is incompatible with the status quo of the system. \\
\hline \multirow{5}{*}{ Economic } & Limited access to capital & The firm does not have sufficient capital for the implementation \\
\hline & Hidden cost & $\begin{array}{l}\text { Investment entails extra costs or the loss of benefits, which are not properly estimated in } \\
\text { the investments analysis. }\end{array}$ \\
\hline & Risk & $\begin{array}{l}\text { There are risks related to the success of the interventions e.g., interruption of production } \\
\text { and losses in quality. }\end{array}$ \\
\hline & Investments cost & High investments costs prevent firms from implementing sustainability interventions. \\
\hline & PBT & $\begin{array}{l}\text { The intervention is not sufficiently profitable, e.g., with low returns and a long period of } \\
\text { time required. }\end{array}$ \\
\hline
\end{tabular}


Table 2. Drivers literature review. The table reports all the contributions considered in the literature review for each area (i.e. IS, OHS, EcoEff, EnEff). The table is organized in order to provide, for each contribution, the followings: i) Authors and year; ii) Journal; iii) Type of study: theoretical (authors develop a theoretical model without any empirical application), empirical (authors provide an empirical application, e.g. case studies, survey, of a model developed in another contribution) or both of them (authors develop a theoretical model and provide an empirical application on it), according to the distinction already made in (Martín-Peña et al., 2014; Murillo-Luna et al., 2011; Seuring, 2013); iv) Organization of drivers, i.e. the way in which drivers are presented in the study: listed (presented as a list), grouped (organized in categories), ranked (ranked according to their relevance); v) Context: geographical areas and sectors on which the contribution focuses (if any); vi) Main findings: main insights emerged.

\begin{tabular}{|l|c|c|c|c|}
\hline Authors and Year & Journal & $\begin{array}{c}\text { Type of } \\
\text { study }\end{array}$ & Organization & Context \\
& & of drivers & \\
\hline
\end{tabular}

\begin{tabular}{|c|c|c|c|c|c|c|}
\hline \multirow{2}{*}{\multicolumn{2}{|c|}{\begin{tabular}{|c|} 
Azapagic and Perdan, 2000 \\
Gabzdylova et al., 2009
\end{tabular}}} & Trans IChemE & $\mathrm{T}$ & Listed & - & Public opinion, improving firm's image, adoption of certification \\
\hline & & $\begin{array}{l}\text { Journal of Cleaner } \\
\text { Production }\end{array}$ & E & Ranked & $\begin{array}{l}\text { Wine industry; New } \\
\text { Zealand }\end{array}$ & Environmental Values, Commitment, Product quality \\
\hline \multirow{11}{*}{$\approx$} & Collins et al., 2010 & $\begin{array}{l}\text { Business Strategy and } \\
\text { the Environment }\end{array}$ & $\mathrm{E}$ & Ranked & New Zealand & $\begin{array}{l}\text { Internal: Values and beliefs, Employees, Shareholders, Parent firm } \\
\text { External: Customers, Government (local and central), Competitors, } \\
\text { Pressure groups }\end{array}$ \\
\hline & Koho et al., 2011 & $\begin{array}{l}\text { International } \\
\text { Symposium on } \\
\text { Assembly and } \\
\text { Manufacturing } 2011\end{array}$ & $\mathrm{E}$ & Ranked & Spain & Business strategy; Values; Top management support \\
\hline & Arruda et al., 2013 & Sustainability & $\mathrm{E}$ & Ranked & $\begin{array}{l}\text { Heavy construction } \\
\text { industry; Les; Brazil }\end{array}$ & $\begin{array}{l}\text { Changes in production standards, economic globalization, contractor } \\
\text { demands and environmental laws. }\end{array}$ \\
\hline & Santini et al., 2013 & $\begin{array}{l}\text { Agricultural and Food } \\
\text { Economics }\end{array}$ & $\mathrm{T}$ & Listed & - & $\begin{array}{l}\text { Institutions, associations, regulators and market demand; } \\
\text { Entrepreneurs and top management; Sustainability and strategy }\end{array}$ \\
\hline & Bocken et al., 2014 & $\begin{array}{l}\text { Journal of Cleaner } \\
\text { Production }\end{array}$ & $\mathrm{T}$ & Listed & - & $\begin{array}{l}\text { Technology advancement, Level of innovation, Systems perspective, } \\
\text { Innovative approaches to collaboration, Education and Awareness }\end{array}$ \\
\hline & Kara et al., 2014 & $\begin{array}{l}\text { Journal of } \\
\text { Manufacturing } \\
\text { Technology } \\
\text { Management }\end{array}$ & E & Presented & $\begin{array}{l}\text { OEM, ETM, Recycling; } \\
\text { Asia, Australia, EU, USA }\end{array}$ & $\begin{array}{l}\text { Firm image, Environmental responsibility, Long term market, } \\
\text { Economic benefits, Legislation }\end{array}$ \\
\hline & Klewitz and Hansen 2014 & $\begin{array}{l}\text { Journal of Cleaner } \\
\text { Production }\end{array}$ & $\mathrm{T}$ & Listed & - & $\begin{array}{l}\text { Values of owner-manager (and staff), Environmental regulation, } \\
\text { Pressure groups, Reputation, talent attraction, New } \\
\text { consumer/consumer needs }\end{array}$ \\
\hline & Schrettle et al., 2014 & $\begin{array}{l}\text { International Journal of } \\
\text { Production Economics }\end{array}$ & $\mathrm{T}$ & Grouped & - & $\begin{array}{l}\text { Exogenous: Environmental regulation, Societal values and norms, } \\
\text { Market drivers } \\
\text { Endogenous: Culture, Strategy, Resources }\end{array}$ \\
\hline & Sy, 2014 & $\begin{array}{l}\text { Industrial Engineering } \\
\text { and Management } \\
\text { Systems }\end{array}$ & E & Presented & Philippines and Thailand & $\begin{array}{l}\text { Economic responsibility, Legal responsibility, Environmental } \\
\text { responsibility }\end{array}$ \\
\hline & Fonseca, 2015 & Sustainability & E & Ranked & Portugal & $\begin{array}{l}\text { Internal context, external context, stakeholder orientation, managers' } \\
\text { satisfaction }\end{array}$ \\
\hline & Kuçksayraç, 2015 & $\begin{array}{l}\text { Journal of Cleaner } \\
\text { Production }\end{array}$ & E & Ranked & Turkey & $\begin{array}{l}\text { Research and development, education and training, education and } \\
\text { standards }\end{array}$ \\
\hline
\end{tabular}




\begin{tabular}{|c|c|c|c|c|c|}
\hline Lijo and Gopalakrishnan, 2015 & $\begin{array}{l}\text { World Journal of } \\
\text { Science, Technology } \\
\text { and Sustainable } \\
\text { Development }\end{array}$ & $\mathrm{T} / \mathrm{E}$ & Grouped & - & $\begin{array}{l}\text { Long term customer relationship, resource scarcity, product } \\
\text { stewardship, ecological responsibility, long term selection of } \\
\text { technology, image, brand, social identity for the firm }\end{array}$ \\
\hline Lozano, 2015 & $\begin{array}{l}\text { Corporate Social } \\
\text { Responsibility and the } \\
\text { Environmental } \\
\text { Management }\end{array}$ & $\mathrm{T} / \mathrm{E}$ & Listed & - & $\begin{array}{l}\text { Internal: Proactive leadership, Business case, Firm's culture } \\
\text { External: Reputation, Customers demand and expectations, } \\
\text { Regulations and legislation }\end{array}$ \\
\hline Merli et al., 2015 & Sustainability & E & Ranked & Italy & $\begin{array}{l}\text { Improving image, increasing employee satisfaction, obtaining } \\
\text { competitive advantages (SMEs ad LEs), Attracting new customers } \\
\text { (Micros) }\end{array}$ \\
\hline Lloret, 2016 & $\begin{array}{l}\text { Journal of Business } \\
\text { Research }\end{array}$ & $\mathrm{E}$ & Ranked & Mexico & Firm reputation, new market opportunities, cost saving, brand \\
\hline $\begin{array}{l}\text { Suriyankietkaew and Avery, } \\
2016\end{array}$ & Sustainability & E & Ranked & SMEs, Thai & $\begin{array}{l}\text { Amicable labour relations, valuing employees, social responsibility, } \\
\text { strong and shared vision }\end{array}$ \\
\hline
\end{tabular}

\begin{tabular}{|c|c|c|c|c|c|c|}
\hline & Pransky et al., 1999 & Ergonomics & $\mathrm{T} / \mathrm{E}$ & Listed & Manufacturing, LEs, USA & Incentive programmes \\
\hline & Tait and Walker, 2000 & $\begin{array}{l}\text { Journal of Safety } \\
\text { Research }\end{array}$ & $\mathrm{E}$ & Ranked & UK & $\begin{array}{l}\text { Awards, Lead to increasing motivations and further investment in } \\
\text { health and safety }\end{array}$ \\
\hline & ENWHP, 2001 & Report & $\mathrm{E}$ & Ranked & SMEs, Europe & $\begin{array}{l}\text { Integrate workplace health issues in the daily management practices, } \\
\text { Involvement of employees, Exemplary leadership behaviour }\end{array}$ \\
\hline & Antonsson et al., 2002 & Report & $\mathrm{E}$ & Ranked & SMEs, Sweden & Support network, tailored legislation, intermediaries \\
\hline & Roy et al., 2003 & Conference & $\mathrm{E}$ & Ranked & Canada & Knowledge, Collaboration with network of companies \\
\hline & $\begin{array}{l}\text { Vecchio-Sadus and Griffiths, } \\
2004\end{array}$ & Safety Science & $\mathrm{T} / \mathrm{E}$ & Grouped & Australia & $\begin{array}{l}\text { Synergies between OHS and business and proactivity, } \\
\text { Communication, Reward and recognition }\end{array}$ \\
\hline & Walker and Tait, 2004 & Safety Science & E & Ranked & SMEs, UK & $\begin{array}{l}\text { External support (intermediaries), Training program for SMEs, } \\
\text { Collaboration with others stakeholders }\end{array}$ \\
\hline 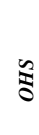 & Gangwar and Goodrum, 2005 & $\begin{array}{l}\text { Construction } \\
\text { Management and } \\
\text { Economics }\end{array}$ & $\mathrm{E}$ & Ranked & Construction industry, USA & Incentive awards, Individual personal motivation \\
\hline & Hasle and Limborg, 2006 & Industrial Health & $\mathrm{T}$ & Listed & SMEs & $\begin{array}{l}\text { External support (intermediaries, unions, authorities, companies), } \\
\text { Dialogue }\end{array}$ \\
\hline & Kogi, 2006 & Industrial Health & $\mathrm{E}$ & Ranked & SMEs, Asia & Participation, Communication \\
\hline & Vecchio-Sadus, 2007 & Safety Science Monitor & $T / E$ & Listed & Australia & Communication \\
\hline & Sims, 2008 & Thesis dissertation & $\mathrm{T} / \mathrm{E}$ & Grouped & - & External incentives, Management attitude, Organization \\
\hline & Miller and Haslam, 2009 & Safety Science & $\mathrm{E}$ & Ranked & UK & $\begin{array}{l}\text { Business case approach, concern about corporate responsibility and } \\
\text { reputations, legal compliance }\end{array}$ \\
\hline & Hale et al., 2010 & Safety Science & E & Ranked & - & Culture, Communication, Motivation \\
\hline & Cagno et al., 2011 & Safety Science & $\mathrm{E}$ & Ranked & SMEs & Collaboration, ICT tools \\
\hline & Cagno et al., 2016 & Safety Science & $T / E$ & Listed & - & $\begin{array}{l}\text { External support of consultants Knowledge of effective } \\
\text { interventions, ICT tools, Collaboration with networks }\end{array}$ \\
\hline
\end{tabular}

\begin{tabular}{|l|l|l|l|l|l|l|}
\hline & Van Hemel and Cramer, 2002 & Journal of Cleaner & T/E & Grouped & SMEs, Holland & External: Customer demands, government regulation, Suppliers \\
development \\
Internal: Environmental benefit, cost reduction, image improvement
\end{tabular}




\begin{tabular}{|c|c|c|c|c|c|}
\hline Altham, 2007 & $\begin{array}{l}\text { Journal of Cleaner } \\
\text { Production }\end{array}$ & E & Ranked & Australia, SMEs & Economic benefits, maintaining licence to operate \\
\hline Masurel, 2007 & $\begin{array}{l}\text { Business Strategy and } \\
\text { the Environment }\end{array}$ & $\mathrm{E}$ & Ranked & Printing, SMEs, Holland & Improving working conditions, Legislation, Moral Duty \\
\hline Fernandez-Viné et al., 2010 & $\begin{array}{l}\text { Journal of Cleaner } \\
\text { Production }\end{array}$ & $\mathrm{T} / \mathrm{E}$ & Grouped & $\begin{array}{l}\text { Food, chemical, textile, } \\
\text { wood, paper, SMEs, } \\
\text { Venezuela }\end{array}$ & Market pressure, economic taxes, legal requirements \\
\hline Santolaria et al., 2011 & $\begin{array}{l}\text { Journal of Cleaner } \\
\text { Production }\end{array}$ & $\mathrm{T} / \mathrm{E}$ & Listed & SMEs and LEs, Spain & $\begin{array}{l}\text { Environmental impact reduction, energy efficiency, marketing and } \\
\text { brand value, legislation adjustment }\end{array}$ \\
\hline Dagiliūtè and Juknys, 2012 & $\begin{array}{l}\text { Journal of Cleaner } \\
\text { Production }\end{array}$ & $\mathrm{E}$ & Ranked & Lithuania & Market economy, Modern technologies, Increased in energy price \\
\hline Brammer et al., 2012 & $\begin{array}{l}\text { Business strategy and } \\
\text { the Environment }\end{array}$ & $\mathrm{E}$ & Ranked & $\begin{array}{l}\text { Extractive, metals and } \\
\text { engineering, chemicals, } \\
\text { printing and paper and } \\
\text { timber sectors, SMEs, UK }\end{array}$ & $\begin{array}{l}\text { Legislative compliance, Long term financial benefits, Customer } \\
\text { pressure }\end{array}$ \\
\hline Fernandez-Viné et al., 2013 & $\begin{array}{l}\text { Journal of Cleaner } \\
\text { Production }\end{array}$ & $\mathrm{T} / \mathrm{E}$ & Grouped & $\begin{array}{l}\text { Manufacturing, SMEs, } \\
\text { Venezuela }\end{array}$ & Decreasing costs, improving the quality of products, legislation \\
\hline Mittal et al., 2013 & $\begin{array}{l}\text { Conference Proceeding, } \\
\text { 20th CIRP International } \\
\text { Conference }\end{array}$ & $\mathrm{T} / \mathrm{E}$ & Listed & India and Germany & Legislation, cost savings, top management commitment \\
\hline De Medeiros et al., 2014 & $\begin{array}{l}\text { Journal of Cleaner } \\
\text { Production }\end{array}$ & $\mathrm{T} / \mathrm{E}$ & Grouped & $\begin{array}{l}\text { Experts in product } \\
\text { development }\end{array}$ & $\begin{array}{l}\text { R\&D, marketing and production integration, Stakeholder, } \\
\text { integration (suppliers, universities, environment specialists, etc.), } \\
\text { Customer expectation fulfilment and Knowledge about factors that } \\
\text { drive sustainable buying }\end{array}$ \\
\hline Govindan et al., 2015 & $\begin{array}{l}\text { Journal of Cleaner } \\
\text { Production }\end{array}$ & $\mathrm{T} / \mathrm{E}$ & Listed & $\begin{array}{l}\text { Chemical, Food, Iron and } \\
\text { Steel, Automotive } \\
\text { components, Textile, Paper, } \\
\text { Electrical, LEs, India }\end{array}$ & Compliance with regulation, stakeholders, customers \\
\hline Mittal and Sangwan, 2015 & $\begin{array}{l}\text { Journal of Multi- } \\
\text { Criteria Decision } \\
\text { Analysis }\end{array}$ & $\mathrm{E}$ & Ranked & $\begin{array}{l}\text { Different perspectives; } \\
\text { government, industry } \\
\text { experts }\end{array}$ & Competitiveness, Incentives, Organizational resources \\
\hline Ghazilla et al., 2015 & $\begin{array}{l}\text { Conference Proceeding, } \\
\text { 12th Global Conference } \\
\text { on Sustainable } \\
\text { Manufacturing }\end{array}$ & $\mathrm{E}$ & Ranked & $\begin{array}{l}\text { Manufacturing, SMEs, } \\
\text { Malaysia }\end{array}$ & $\begin{array}{l}\text { Improved company image, perception of increased product quality, } \\
\text { business performances }\end{array}$ \\
\hline Bossle et al., 2016 & $\begin{array}{l}\text { Journal of Cleaner } \\
\text { Production }\end{array}$ & $\mathrm{T}$ & Grouped & - & $\begin{array}{l}\text { External: regulatory requests market demand, cooperation and } \\
\text { redevelopment of industrial technology } \\
\text { Internal: efficiency, environmental capability, environmental } \\
\text { managerial concern, human resources and environmental strategy }\end{array}$ \\
\hline Hojnik and Ruzzier, 2016 & $\begin{array}{l}\text { Environmental } \\
\text { Innovation and Societal } \\
\text { Transitions }\end{array}$ & $\mathrm{T}$ & Listed & - & $\begin{array}{l}\text { Regulation and market pull factors, Cost saving, Technology push } \\
\text { factors }\end{array}$ \\
\hline
\end{tabular}

\begin{tabular}{|c|c|c|c|c|c|c|}
\hline \multirow{4}{*}{$\begin{array}{l}\text { ज्ञ } \\
\text { जे }\end{array}$} & De Groot et al., 2001 & Energy Economics & $\mathrm{E}$ & Ranked & Netherlands & Reduction of cost, Green image, Investment subsides \\
\hline & Anderson and Newell, 2004 & $\begin{array}{l}\text { Resource and Energy } \\
\text { Economics }\end{array}$ & $\mathrm{E}$ & Ranked & $\begin{array}{l}\text { Manufacturing, SMEs, } \\
\text { USA }\end{array}$ & Publicly financed energy audits \\
\hline & Rohdin and Thollander, 2006 & Energy & $\mathrm{E}$ & Ranked & $\begin{array}{l}\text { Non-energy intensive } \\
\text { Manufacturing, Sweden }\end{array}$ & Long term strategy, Increasing in energy price, Commitment \\
\hline & Thollander et al., 2007 & Energy Policy & $\mathrm{E}$ & Ranked & $\begin{array}{l}\text { Manufacturing, SMEs, } \\
\text { Sweden }\end{array}$ & Long term strategy, Commitment, Environmental company profile \\
\hline
\end{tabular}




\begin{tabular}{|c|c|c|c|c|c|}
\hline Rohdin et al., 2007 & Energy Policy & E & Ranked & Foundry, Sweden & Long term strategy, Commitment, Environmental company profile \\
\hline Thollander and Ottosson, 2008 & Energy Efficiency & E & Ranked & Pulp and paper, Sweden & Cost reduction, Commitment, Long term strategy \\
\hline Hasanbeigi et al., 2010 & Energy Efficiency & $\mathrm{E}$ & Ranked & $\begin{array}{l}\text { Textile industry, Cement } \\
\text { industry, Thai }\end{array}$ & $\begin{array}{l}\text { Reducing costs (related also to Increasing in energy price), } \\
\text { Improving staff Health and Safety, Improving product quality }\end{array}$ \\
\hline Ren, 2009 & $\begin{array}{l}\text { Journal of Engineering } \\
\text { and Technology } \\
\text { Management }\end{array}$ & $\mathrm{E}$ & Ranked & Petrochemical, OECD & Cost reduction, Fierce competition, Commitment \\
\hline Apeaning and Thollander, 2013 & $\begin{array}{l}\text { Journal of cleaner } \\
\text { Production }\end{array}$ & $\mathrm{E}$ & Ranked & Industrial, Ghana & Cost reduction, Rising in energy prices, Government compliance \\
\hline Cagno and Trianni, 2013 & Applied Energy & $\mathrm{E}$ & Ranked & Manufacturing, Italy & $\begin{array}{l}\text { Allowances or public financing, External pressures, Long-term } \\
\text { benefits }\end{array}$ \\
\hline Thollander et al., 2013 & Applied Energy & $\mathrm{E}$ & Ranked & $\begin{array}{l}\text { Foundry, Finland, France, } \\
\text { Germany, Italy, Poland, } \\
\text { Spain, Sweden }\end{array}$ & Financial, Organizational, External \\
\hline Brunke et al., 2014 & $\begin{array}{l}\text { Journal of cleaner } \\
\text { Production }\end{array}$ & $\mathrm{E}$ & Ranked & Iron and Steel, Sweden & Cost reduction, Management commitment, Long term strategy \\
\hline Sudhakara Reddy et al., 2014 & $\begin{array}{l}\text { Energy Conservation } \\
\text { and Management }\end{array}$ & $\mathrm{T}$ & Listed & - & $\begin{array}{l}\text { Awareness, decrease in technology price, increase in energy price, } \\
\text { technology appeal, non-energy benefits, environmental regulation }\end{array}$ \\
\hline Venmans, 2014 & $\begin{array}{l}\text { Journal of cleaner } \\
\text { Production }\end{array}$ & $\mathrm{E}$ & Ranked & $\begin{array}{l}\text { Ceramic sector, Cement } \\
\text { sector, Lime sector, SMEs- } \\
\text { LEs, Belgium }\end{array}$ & Cost reduction, Management commitment, Environmental image \\
\hline Lee, 2015 & $\begin{array}{l}\text { Sustainable } \\
\text { Development }\end{array}$ & E & Ranked & Steel industry, Korea & Cost savings, Demand from owner, Energy tax \\
\hline Sathitbun-anan et al., 2015 & Energy Efficiency & $\mathrm{E}$ & Ranked & $\begin{array}{l}\text { Sugar industry, SMEs-LEs, } \\
\text { Thai }\end{array}$ & Green image, Reducing energy, Subsides \\
\hline Trianni et al., 2016 & Energy Efficiency & $\mathrm{T}$ & Grouped & Industrial & Regulatory, Economic, Informative \\
\hline
\end{tabular}


Table 3. Sample investigated. For each firm of the sample the following are reported: Sector, Number of Employees, Turnover, Persons interviewed.

\begin{tabular}{|c|c|c|c|c|}
\hline Firm & Sector & $\begin{array}{l}\text { Number of } \\
\text { employees }\end{array}$ & Turnover & Persons interviewed \\
\hline Firm 1 & Manufacture of actuators & 118 & $40 \mathrm{M} €$ & OHS manager; OHS assistant \\
\hline Firm 2 & $\begin{array}{l}\text { Manufacture of precision mechanics } \\
\text { components }\end{array}$ & 160 & $16 \mathrm{M} €$ & $\begin{array}{l}\text { Health, Safety and Environment } \\
\text { Manager }\end{array}$ \\
\hline Firm 3 & $\begin{array}{l}\text { Manufacture of plastic packaging for } \\
\text { beauty and home }\end{array}$ & 320 & $140 \mathrm{M} €$ & Sustainability and quality manager \\
\hline Firm 4 & $\begin{array}{l}\text { Manufacture of bathroom wooden } \\
\text { furniture }\end{array}$ & 108 & $18 \mathrm{M} €$ & $\begin{array}{l}\text { Technical director; OHS and } \\
\text { environment manager }\end{array}$ \\
\hline Firm 5 & Manufacture of compressors & 400 & $49 \mathrm{M} €$ & $\begin{array}{l}\text { Health, Safety and Environment } \\
\text { manager }\end{array}$ \\
\hline Firm 6 & Manufacture of mechanical components & 180 & $135 \mathrm{M} €$ & OHS manager \\
\hline Firm 7 & $\begin{array}{l}\text { Manufacture of steel and polyethylene } \\
\text { pipes }\end{array}$ & 170 & $30 \mathrm{M} €$ & OHS and environment manager \\
\hline Firm 8 & Manufacture of vehicles chassis & 120 & $60 \mathrm{M} €$ & $\begin{array}{l}\text { Plant manager; Health, Safety and } \\
\text { Environment manager }\end{array}$ \\
\hline Firm 9 & $\begin{array}{l}\text { Manufacture of domestic heater and } \\
\text { integrated thermal system }\end{array}$ & 400 & $70 \mathrm{M} €$ & $\begin{array}{l}\text { Quality and Health, Safety and } \\
\text { Environment manager }\end{array}$ \\
\hline
\end{tabular}




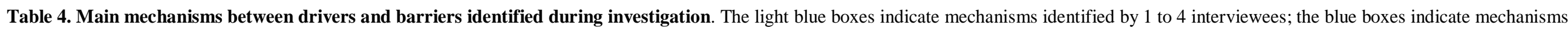
identified by 5 to 8 interviewees; the dark blue boxes indicate mechanisms identified by 9 to 12 interviewees.

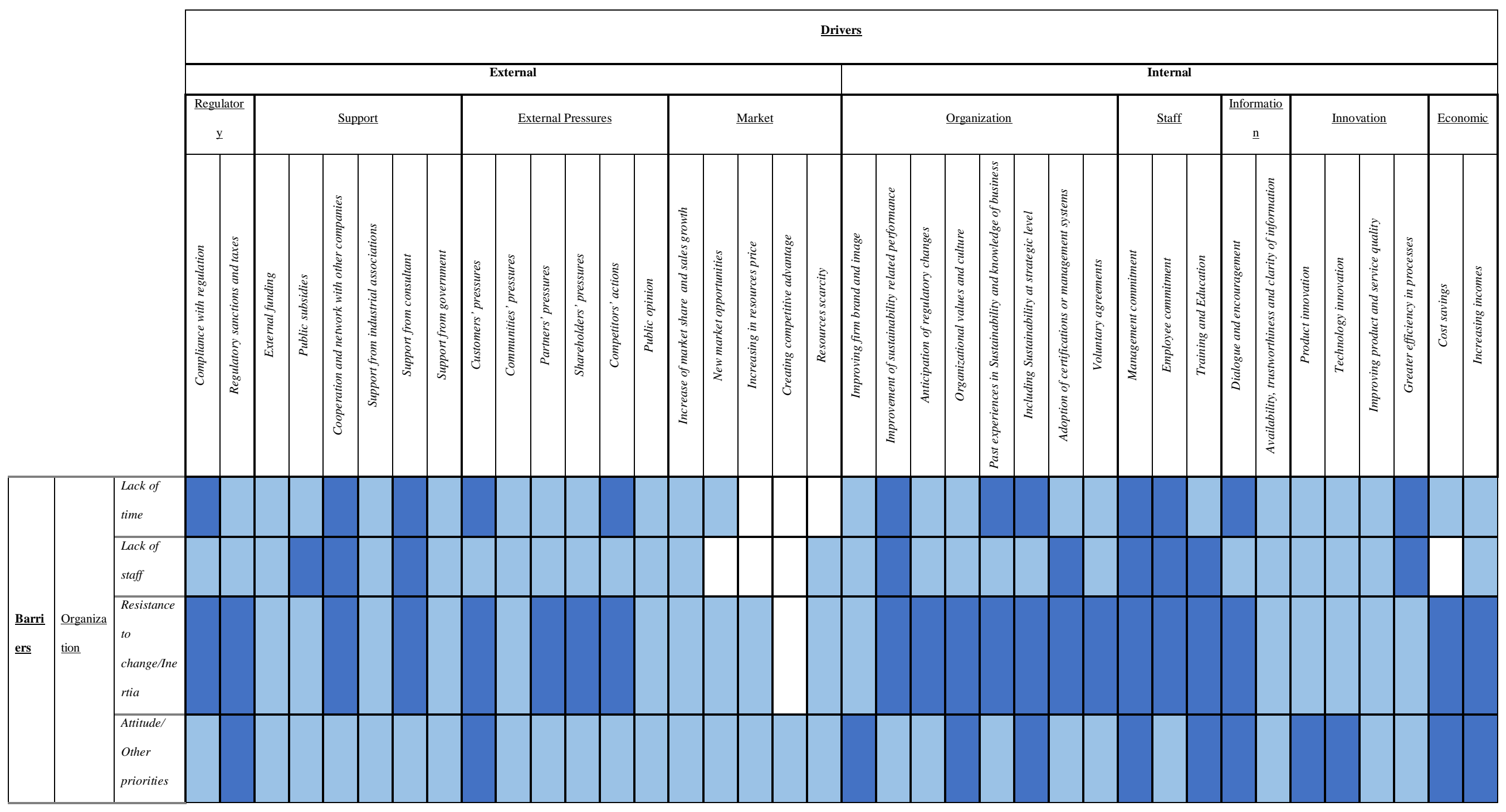




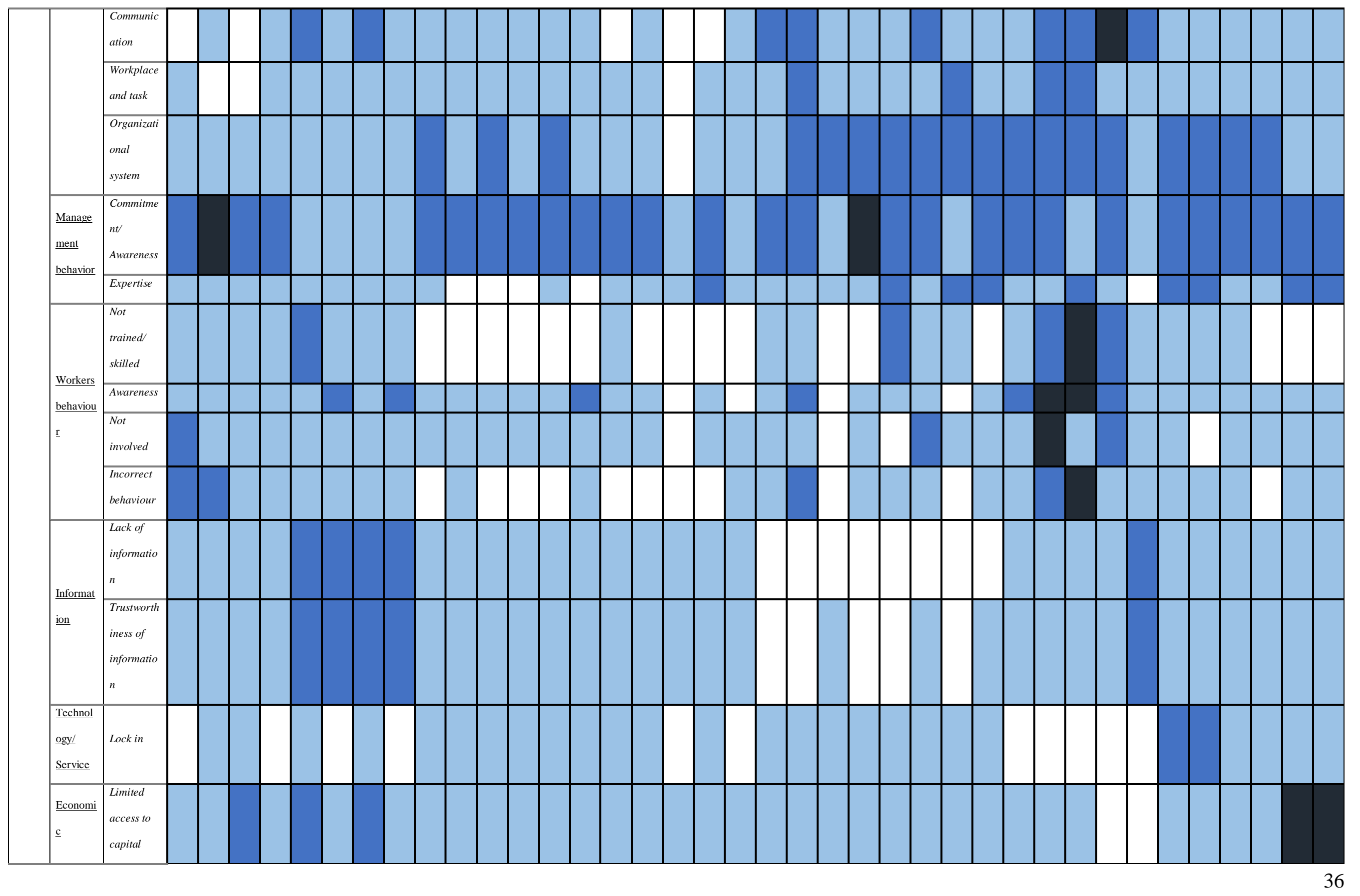




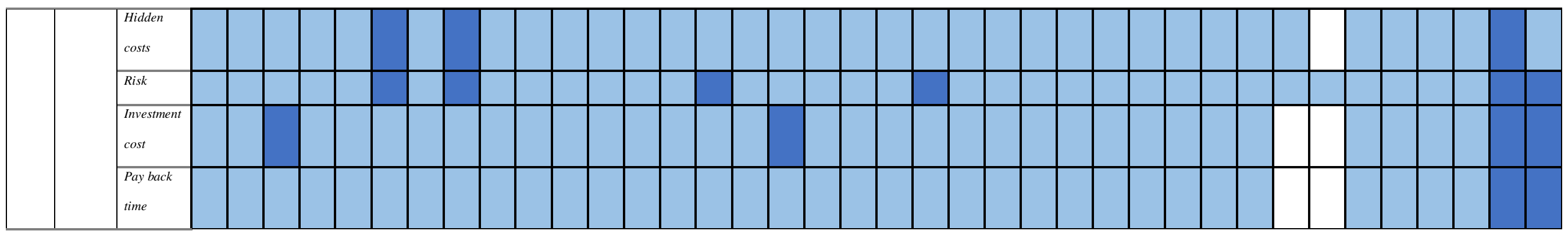




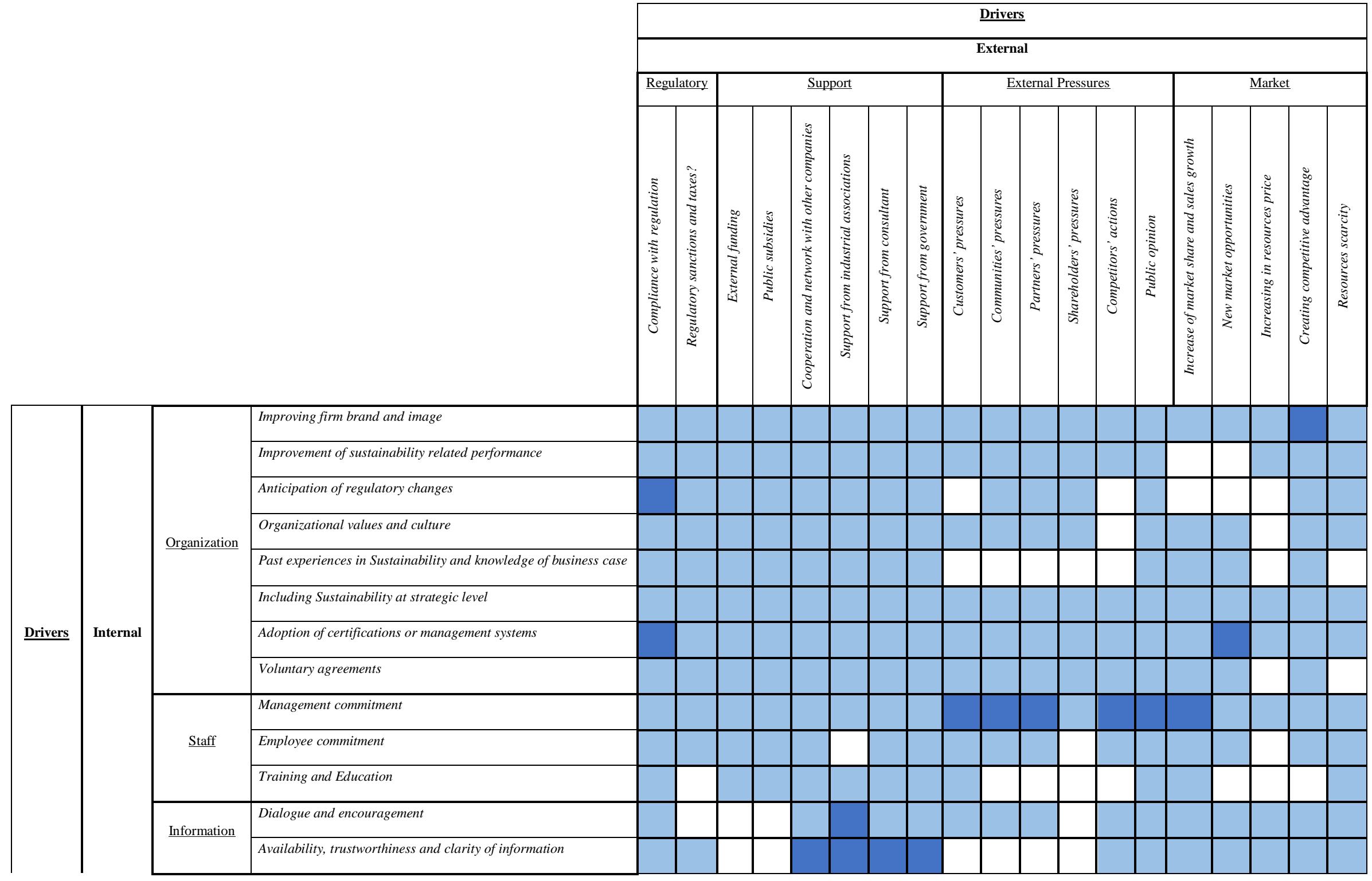




$\| H=$


Table 6. Main mechanisms between enabler (internal) drivers and simple drivers identified during investigation. The light blue boxes indicate mechanisms identified by 1 to 4 interviewees; the blue boxes indicate mechanisms identified by 5 to 8 interviewees; the dark blue boxes indicate mechanisms identified by 9 to 12 interviewees.

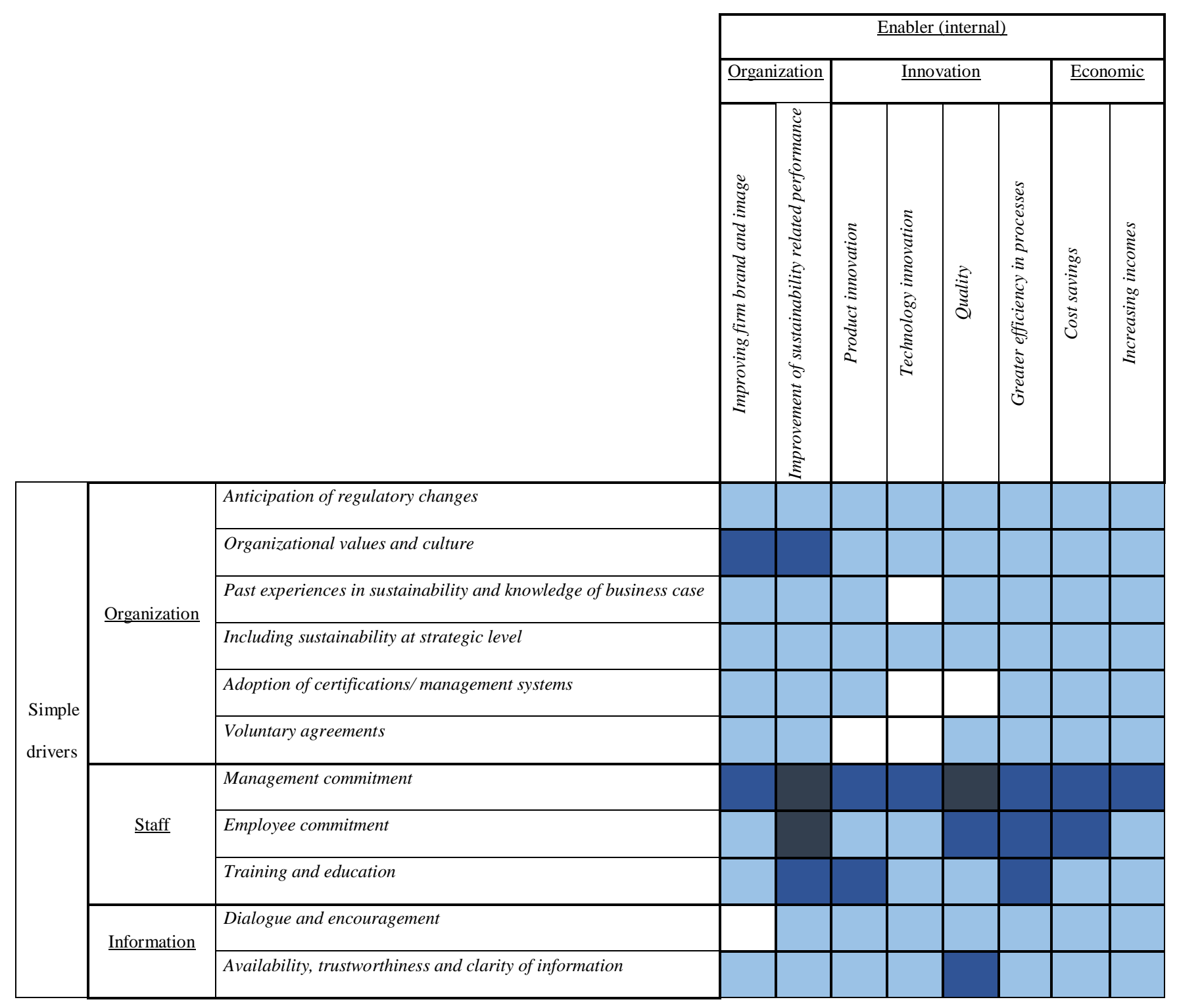




\section{Annex}

Table A1. The new model for drivers for the adoption of industrial sustainability measures. Categories are divided, according to their origin in External and Internal. For each driver, references are provided for each of the four areas considered in the literature review. In the last column, the type of driver is specified, i.e. Enabler (external), Enabler (internal) or Simple.

\begin{tabular}{|c|c|c|c|c|}
\hline Origin & Category & Driver & References & Type \\
\hline \multirow{4}{*}{ External } & \multirow[t]{2}{*}{$\underline{\text { Regulatory }}$} & $\begin{array}{l}\text { Compliance with } \\
\text { regulation }\end{array}$ & $\begin{array}{l}\text { IS: Arruda et al., 2013; Gabzdylova et al., 2009; Kara et al., 2014; Klewitz and } \\
\text { Hansen, 2014; Küçüksayraç, 2015; Lozano, 2015; Schrettle et al., 2014; Sy, } 2014 \\
\text { OHS: Cagno et al., 2016; EASHW, 2010; Miller and Haslam, 2009; Walker and } \\
\text { Tait, } 2004 \\
\text { EcoEff: Altham, 2007; Brammer et al., 2012; De Medeiros et al., 2014; Del Río } \\
\text { González, 2005; Ekins, 2005; Fernández-Viñé et al., 2013, 2010; Ghazilla et al., } \\
\text { 2015; Hojnik and Ruzzier, 2016; Masurel, 2007; Mittal et al., 2013; Mittal and } \\
\text { Sangwan, 2015; Van Hemel and Cramer, 2002 } \\
\text { EnEff: Apeaning and Thollander, 2013; Brunke et al., 2014; Hasanbeigi et al., } \\
\text { 2010; Johansson and Thollander, 2018; Sathitbun-anan et al., 2015; Sudhakara } \\
\text { Reddyt al., 2014; Thollander et al., 2013; Thollander and Ottosson, 2008; } \\
\text { Venmans, 2014 }\end{array}$ & $\begin{array}{l}\text { Enabler } \\
\text { (external) }\end{array}$ \\
\hline & & $\begin{array}{l}\text { Regulatory sanctions } \\
\text { and taxes }\end{array}$ & $\begin{array}{l}\text { OHS: Cagno et al., } 2016 \\
\text { EcoEff: Ghazilla et al., 2015; Santolaria et al., } 2011 \\
\text { EnEff: Abeelen et al., 2013; Apeaning and Thollander, 2013; Lee, 2015; } \\
\text { Sathitbun-anan et al., 2015; Thollander et al., } 2013\end{array}$ & $\begin{array}{l}\text { Enabler } \\
\text { (external) }\end{array}$ \\
\hline & \multirow[t]{2}{*}{$\underline{\text { Support }}$} & External funding & $\begin{array}{l}\text { IS: Merli et al., } 2015 \\
\text { OHS: Cagno et al., 2016, 2011; Gangwar and Goodrum, 2005; Sims, 2008; Tait } \\
\text { and Walker, } 2000 \\
\text { EcoEff: De Medeiros et al., 2014; Del Río González, 2005; Ghazilla et al., 2015; } \\
\text { Govindan et al., 2015; Hojnik and Ruzzier, 2016; Mittal et al., 2013; Mittal and } \\
\text { Sangwan, } 2015 \\
\text { EnEff: Apeaning and Thollander, 2013; Brunke et al., 2014; De Groot et al., } \\
\text { 2001; Johansson and Thollander, 2018; Lee, 2015; Rohdin et al., 2007; } \\
\text { Thollander and Ottosson, 2008; Trianni et al., 2017a }\end{array}$ & $\begin{array}{l}\text { Enabler } \\
\text { (external) }\end{array}$ \\
\hline & & Public subsidies & $\begin{array}{l}\text { OHS: Cagno et al., 2016, 2011; Gangwar and Goodrum, } 2005 \\
\text { EcoEff: De Medeiros et al., 2014; Del Río González, 2005; Ghazilla et al., 2015; } \\
\text { Govindan et al., 2015; Mittal et al., 2013; Mittal and Sangwan, 2015; Santolaria et } \\
\text { al., } 2011 \\
\text { EnEff: Anderson and Newell, 2004; Brunke et al., 2014; Cagno and Trianni, } \\
\text { 2013; De Groot et al., 2001; Johansson and Thollander, 2018; Lee, 2015; } \\
\text { Sathitbun-anan et al., 2015; Thollander et al., 2013; Thollander and Ottosson, } \\
\text { 2008; Trianni et al., 2017a }\end{array}$ & $\begin{array}{l}\text { Enabler } \\
\text { (external) }\end{array}$ \\
\hline
\end{tabular}




\begin{tabular}{|c|c|c|c|}
\hline & $\begin{array}{l}\text { Cooperation and } \\
\text { network with other } \\
\text { companies }\end{array}$ & $\begin{array}{l}\text { IS: Lozano, } 2015 \\
\text { OHS: Antonsson et al., 2002; Cagno et al., 2016; Hasle and Limborg, 2006; } \\
\text { Vecchio-Sadus and Griffiths, } 2004 \\
\text { EcoEff: Bossle et al., 2016; De Medeiros et al., 2014; Fernández-Viñé et al., } \\
\text { 2010; Ghazilla et al., 2015; Hojnik and Ruzzier, } 2016 \\
\text { EnEff: Apeaning and Thollander, 2013; Brunke et al., 2014; Johansson and } \\
\text { Thollander, 2018; Lee, 2015; Sathitbun-anan et al., 2015; Thollander et al., 2013; } \\
\text { Thollander and Ottosson, 2008; Trianni et al., 2017a }\end{array}$ & $\begin{array}{l}\text { Enabler } \\
\text { (external) }\end{array}$ \\
\hline & $\begin{array}{l}\text { Support from industrial } \\
\text { associations }\end{array}$ & $\begin{array}{l}\text { OHS: Cagno et al., 2016, 2011; Sims, } 2008 \\
\text { EcoEff: De Medeiros et al., 2014; Ghazilla et al., } 2015 \\
\text { EnEff: Brunke et al., 2014; Cagno and Trianni, 2013; Johansson and Thollander, } \\
\text { 2018; Lee, 2015; Thollander et al., 2013; Thollander and Ottosson, } 2008\end{array}$ & $\begin{array}{l}\text { Enabler } \\
\text { (external) }\end{array}$ \\
\hline & $\begin{array}{l}\text { Support from } \\
\text { consultants }\end{array}$ & $\begin{array}{l}\text { OHS: Antonsson et al., 2002; Cagno et al., 2016; Hasle and Limborg, } 2006 \\
\text { EcoEff: Bossle et al., 2016; Ghazilla et al., } 2015 \\
\text { EnEff: Johansson and Thollander, 2018; Lee, 2015; Thollander et al., 2013; } \\
\text { Thollander and Ottosson, 2008; Trianni et al., 2017a }\end{array}$ & $\begin{array}{l}\text { Enabler } \\
\text { (external) }\end{array}$ \\
\hline & $\begin{array}{l}\text { Support from } \\
\text { government }\end{array}$ & $\begin{array}{l}\text { OHS:Cagno et al., } 2016 \\
\text { EcoEff: De Medeiros et al., 2014; Fernández-Viñé et al., } 2013 \\
\text { EnEff: Brunke et al., 2014; Cagno and Trianni, 2013; Johansson and Thollander, } \\
\text { 2018; Thollander et al., 2013; Trianni et al., 2017a }\end{array}$ & $\begin{array}{l}\text { Enabler } \\
\text { (external) }\end{array}$ \\
\hline \multirow[t]{3}{*}{$\begin{array}{l}\text { External } \\
\underline{\text { Pressures }}\end{array}$} & Customers'pressures & $\begin{array}{l}\text { IS: Collins et al., 2010; Fonseca, 2015; Gabzdylova et al., 2009; Kara et al., 2014; } \\
\text { Klewitz and Hansen, 2014; Küçüksayraç, 2015; Lijo and Gopalakrishnan, 2015; } \\
\text { Lozano, 2015; Santini et al., } 2013 \\
\text { OHS: EASHW, } 2010 \\
\text { EcoEff: Bossle et al., 2016; Brammer et al., 2012; De Medeiros et al., 2014; Del } \\
\text { Río González, 2005; Fernández-Viñé et al., 2013, 2010; Ghazilla et al., 2015; } \\
\text { Govindan et al., 2015; Masurel, 2007; Mittal et al., 2013; Mittal and Sangwan, } \\
\text { 2015; Santolaria et al., 2011; Van Hemel and Cramer, 2002 } \\
\text { EnEff: Aflaki et al., 2013; Brunke et al., 2014; Cagno and Trianni, 2013; } \\
\text { Johansson and Thollander, 2018; Lee, 2015; Thollander et al., 2013; Thollander } \\
\text { and Ottosson, 2008 }\end{array}$ & $\begin{array}{l}\text { Enabler } \\
\text { (external) }\end{array}$ \\
\hline & Communities' pressures & $\begin{array}{l}\text { IS: Collins et al., 2010; Fonseca, 2015; Gabzdylova et al., 2009; Klewitz and } \\
\text { Hansen, 2014; Lozano, } 2015 \\
\text { EcoEff: Del Río González, 2005; Ghazilla et al., 2015; Mittal et al., } 2013 \\
\text { EnEff: Brunke et al., 2014; Cagno and Trianni, 2013; Johansson and Thollander, } \\
\text { 2018; Thollander et al., 2013; Thollander and Ottosson, 2008; Venmans, } 2014\end{array}$ & $\begin{array}{l}\text { Enabler } \\
\text { (external) }\end{array}$ \\
\hline & Partners' pressures & $\begin{array}{l}\text { IS: Collins et al., 2010; Fonseca, 2015; Gabzdylova et al., 2009; Klewitz and } \\
\text { Hansen, 2014; Lozano, } 2015\end{array}$ & $\begin{array}{l}\text { Enabler } \\
\text { (external) }\end{array}$ \\
\hline
\end{tabular}




\begin{tabular}{|c|c|c|c|}
\hline & & $\begin{array}{l}\text { EcoEff: Brammer et al., 2012; Del Río González, 2005; Ghazilla et al., 2015; } \\
\text { Govindan et al., 2015; Hojnik and Ruzzier, 2016; Mittal et al., 2013; Mittal and } \\
\text { Sangwan, 2015; Van Hemel and Cramer, } 2002 \\
\text { EnEff: Cagno and Trianni, } 2013\end{array}$ & \\
\hline & $\begin{array}{l}\text { Shareholders' } \\
\text { pressures }\end{array}$ & $\begin{array}{l}\text { IS: Arruda et al., 2013; Collins et al., 2010; Fonseca, 2015; Gabzdylova et al., } \\
\text { 2009; Klewitz and Hansen, 2014; Lijo and Gopalakrishnan, 2015; Lozano, } 2015 \\
\text { OHS: Walker and Tait, } 2004 \\
\text { EcoEff: Del Río González, 2005; Govindan et al., 2015; Hojnik and Ruzzier, } \\
2016 \\
\text { EnEff: Cagno and Trianni, 2013; Johansson and Thollander, 2018; Sathitbun- } \\
\text { anan et al., 2015; Thollander and Ottosson, 2008; Venmans, } 2014\end{array}$ & $\begin{array}{l}\text { Enabler } \\
\text { (external) }\end{array}$ \\
\hline & Competitors' actions & $\begin{array}{l}\text { IS: Collins et al., } 2010 \\
\text { EcoEff: Del Río González, 2005; Ghazilla et al., 2015; Govindan et al., 2015; } \\
\text { Van Hemel and Cramer, } 2002\end{array}$ & $\begin{array}{l}\text { Enabler } \\
\text { (external) }\end{array}$ \\
\hline & Public opinion & $\begin{array}{l}\text { IS: Azapagic and Perdan, 2000; Collins et al., 2010; Lozano, 2015; Schrettle et } \\
\text { al., } 2014 \\
\text { EE: Brammer et al., 2012; Hojnik and Ruzzier, 2016; Mittal et al., 2013; Mittal } \\
\text { and Sangwan, 2015; Van Hemel and Cramer, } 2002 \\
\text { EnEff: Brunke et al., 2014; Johansson and Thollander, 2018; Thollander et al., } \\
\text { 2013; Thollander and Ottosson, 2008; Venmans, } 2014\end{array}$ & $\begin{array}{l}\text { Enabler } \\
\text { (external) }\end{array}$ \\
\hline \multirow{3}{*}{$\underline{\text { Market }}$} & $\begin{array}{l}\text { Increase of market } \\
\text { share and sales growth }\end{array}$ & $\begin{array}{l}\text { IS: Klewitz and Hansen, 2014; Küçüksayraç, 2015; Lozano, } 2015 \\
\text { EcoEff: Altham, 2007; Bossle et al., 2016; Brammer et al., 2012; Del Río } \\
\text { González, 2005; Hojnik and Ruzzier, } 2016\end{array}$ & $\begin{array}{l}\text { Enabler } \\
\text { (external) }\end{array}$ \\
\hline & $\begin{array}{l}\text { New market } \\
\text { opportunities }\end{array}$ & $\begin{array}{l}\text { IS: Arruda et al., 2013; Gabzdylova et al., 2009; Klewitz and Hansen, 2014; } \\
\text { Küçüksayraç, 2015; Lloret, 2016; Lozano, } 2015 \\
\text { EcoEff: Del Río González, 2005; Ekins, 2005; Fernández-Viñé et al., 2013; } \\
\text { Ghazilla et al., 2015; Hojnik and Ruzzier, 2016; Van Hemel and Cramer, } 2002 \\
\text { EnEff: Sathitbun-anan et al., } 2015\end{array}$ & $\begin{array}{l}\text { Enabler } \\
\text { (external) }\end{array}$ \\
\hline & $\begin{array}{l}\text { Increasing in resources } \\
\text { price }\end{array}$ & $\begin{array}{l}\text { EcoEff: Dagiliūtė and Juknys, 2012; Fernández-Viñé et al., } 2010 \\
\text { EnEff: Abeelen et al., 2013; Anderson and Newell, 2004; Apeaning and } \\
\text { Thollander, 2013; Johansson and Thollander, 2018; Lee, 2015; Rohdin and } \\
\text { Thollander, 2006; Sudhakara Reddyet al., 2014; Thollander et al., 2013; } \\
\text { Thollander and Ottosson, 2008; Trianni et al., 2017a; Venmans, } 2014\end{array}$ & $\begin{array}{l}\text { Enabler } \\
\text { (external) }\end{array}$ \\
\hline
\end{tabular}




\begin{tabular}{|c|c|c|c|c|}
\hline & & $\begin{array}{l}\text { Creating competitive } \\
\text { advantage }\end{array}$ & $\begin{array}{l}\text { IS: Kara et al., } 2014 \\
\text { EcoEff: Fernández-Viñé et al., 2013; Ghazilla et al., 2015; Hojnik and Ruzzier, } \\
\text { 2016; Mittal et al., 2013; Mittal and Sangwan, } 2015 \\
\text { EnEff: Apeaning and Thollander, 2013; Brunke et al., 2014; Hasanbeigi et al., } \\
\text { 2010; Johansson and Thollander, 2018; Lee, 2015; Ren, 2009; Rohdin et al., } \\
\text { 2007; Sathitbun-anan et al., 2015; Thollander et al., 2007; Thollander and } \\
\text { Ottosson, 2008; Trianni et al., 2017a }\end{array}$ & $\begin{array}{l}\text { Enabler } \\
\text { (external) }\end{array}$ \\
\hline & & Resources scarcity & $\begin{array}{l}\text { IS: Lijo and Gopalakrishnan, 2015; Lozano, 2015; Schrettle et al., } 2014 \\
\text { EcoEff: Fernández-Viñé et al., } 2013\end{array}$ & $\begin{array}{l}\text { Enabler } \\
\text { (external) }\end{array}$ \\
\hline \multirow{5}{*}{ Internal } & \multirow{5}{*}{ Organization } & $\begin{array}{l}\text { Improving firm brand } \\
\text { and image }\end{array}$ & $\begin{array}{l}\text { IS: Azapagic and Perdan, 2000; Kara et al., 2014; Klewitz and Hansen, 2014; } \\
\text { Küçüksayraç, 2015; Lijo and Gopalakrishnan, 2015; Lloret, 2016; Lozano, 2015; } \\
\text { Merli et al., } 2015 \\
\text { OHS: Miller and Haslam, } 2009 \\
\text { EcoEff: Del Río González, 2005; Ekins, 2005; Fernández-Viñé et al., 2010; } \\
\text { Ghazilla et al., 2015; Govindan et al., 2015; Masurel, 2007; Mittal et al., 2013; } \\
\text { Mittal and Sangwan, 2015; Santolaria et al., 2011; Van Hemel and Cramer, } 2002 \\
\text { EnEff: Aflaki et al., 2013; De Groot et al., 2001; Hasanbeigi et al., 2010; } \\
\text { Sathitbun-anan et al., 2015; Trianni et al., 2017a; Venmans, } 2014\end{array}$ & $\begin{array}{l}\text { Enabler } \\
\text { (internal) }\end{array}$ \\
\hline & & $\begin{array}{l}\text { Improvement of } \\
\text { sustainability related } \\
\text { performance }\end{array}$ & $\begin{array}{l}\text { EcoEff: Ekins, 2005; Ghazilla et al., 2015; Govindan et al., 2015; Santolaria et } \\
\text { al., 2011; Van Hemel and Cramer, } 2002 \\
\text { EnEff: Aflaki et al., 2013; Apeaning and Thollander, 2013; Hasanbeigi et al., } \\
\text { 2010; Johansson and Thollander, 2018; Lee, 2015; Sathitbun-anan et al., 2015; } \\
\text { Thollander et al., 2013; Thollander and Ottosson, } 2008\end{array}$ & $\begin{array}{l}\text { Enabler } \\
\text { (internal) }\end{array}$ \\
\hline & & $\begin{array}{l}\text { Anticipation of } \\
\text { regulatory changes }\end{array}$ & $\begin{array}{l}\text { IS: Gabzdylova et al., } 2009 \\
\text { EcoEff: Ekins, 2005; Mittal et al., } 2013 \\
\text { EnEff: Cagno and Trianni, } 2013\end{array}$ & Simple \\
\hline & & $\begin{array}{l}\text { Organizational values } \\
\text { and culture }\end{array}$ & $\begin{array}{l}\text { IS: Fonseca, 2015; Gabzdylova et al., 2009; Lijo and Gopalakrishnan, 2015; } \\
\text { Lozano, 2015; Schrettle et al., 2014; Sy, } 2014 \\
\text { OHS: Miller and Haslam, } 2009 \\
\text { EcoEff: Bossle et al., 2016; De Medeiros et al., 2014; Fernández-Viñé et al., } \\
\text { 2013; Ghazilla et al., 2015; Masurel, } 2007 \\
\text { EnEff: Johansson and Thollander, 2018; Sathitbun-anan et al., 2015; Sudhakara } \\
\text { Reddyet al., 2014; Thollander and Ottosson, } 2008\end{array}$ & Simple \\
\hline & & $\begin{array}{l}\text { Past experiences in } \\
\text { sustainability and } \\
\text { knowledge of business } \\
\text { case }\end{array}$ & $\begin{array}{l}\text { IS: Lozano, } 2015 \\
\text { OHS: Cagno et al., 2016; Kogi, } 2006 \\
\text { EcoEff: Ekins, 2005; Ghazilla et al., 2015; Hojnik and Ruzzier, } 2016\end{array}$ & Simple \\
\hline
\end{tabular}




\begin{tabular}{|c|c|c|c|}
\hline & $\begin{array}{l}\text { Including ISainability } \\
\text { at strategic level }\end{array}$ & $\begin{array}{l}\text { IS: Bocken et al., 2014; Koho et al., 2011; Lijo and Gopalakrishnan, 2015; } \\
\text { Santini et al., 2013; Schrettle et al., } 2014 \\
\text { OHS: ENWHP, 2001; Miller and Haslam, } 2009 \\
\text { EcoEff: Ghazilla et al., 2015; Masurel, 2007; Van Hemel and Cramer, } 2002 \\
\text { EnEff: Apeaning and Thollander, 2013; Brunke et al., 2014; Cagno and Trianni, } \\
\text { 2013; Hasanbeigi et al., 2010; Johansson and Thollander, 2018; Lee, 2015; } \\
\text { Rohdin et al., 2007; Rohdin and Thollander, 2006; Sathitbun-anan et al., 2015; } \\
\text { Thollander et al., 2013, 2007; Thollander and Ottosson, 2008; Trianni et al., } \\
\text { 2017a }\end{array}$ & Simple \\
\hline & $\begin{array}{l}\text { Adoption of } \\
\text { certifications/ } \\
\text { management systems }\end{array}$ & $\begin{array}{l}\text { IS: Azapagic and Perdan, 2000; Santini et al., } 2013 \\
\text { EcoEff: Bossle et al., 2016; Del Río González, 2005; Hojnik and Ruzzier, } 2016 \\
\text { EnEff: Apeaning and Thollander, 2013; Brunke et al., 2014; Johansson and } \\
\text { Thollander, 2018; Lee, 2015; Rohdin et al., 2007; Rohdin and Thollander, 2006; } \\
\text { Thollander et al., 2013; Thollander and Ottosson, 2008; Venmans, } 2014\end{array}$ & Simple \\
\hline & Voluntary agreements & $\begin{array}{l}\text { EcoEff: Ekins, 2005; Ghazilla et al., 2015; Hojnik and Ruzzier, 2016; Masurel, } \\
2007 \\
\text { EnEff: Rohdin et al., 2007; Trianni et al., 2017a; Venmans, } 2014\end{array}$ & Simple \\
\hline \multirow{3}{*}{$\underline{\text { Staff }}$} & $\begin{array}{l}\text { Management } \\
\text { commitment }\end{array}$ & $\begin{array}{l}\text { IS: Fonseca, 2015; Gabzdylova et al., 2009; Klewitz and Hansen, 2014; Koho et } \\
\text { al., 2011; Lozano, 2015; Santini et al., } 2013 \\
\text { OHS: Cagno et al., 2011; ENWHP, 2001; Sims, } 2008 \\
\text { EcoEff: Bossle et al., 2016; Del Río González, 2005; Ghazilla et al., 2015; } \\
\text { Hojnik and Ruzzier, 2016; Mittal et al., 2013; Mittal and Sangwan, } 2015 \\
\text { EnEff: Brunke et al., 2014; Cagno and Trianni, 2013; Hasanbeigi et al., 2010; } \\
\text { Johansson and Thollander, 2018; Lee, 2015; Ren, 2009; Sathitbun-anan et al., } \\
\text { 2015; Thollander et al., 2013; Trianni et al., 2017a; Venmans, } 2014\end{array}$ & Simple \\
\hline & Employee commitment & $\begin{array}{l}\text { IS: Gabzdylova et al., 2009; Lozano, 2015; Sy, } 2014 \\
\text { OHS: Cagno et al., 2011; Vecchio-Sadus and Griffiths, } 2004 \\
\text { EcoEff: Bossle et al., 2016; Ghazilla et al., 2015; Govindan et al., 2015; } \\
\text { Masurel, } 2007 \\
\text { EnEff: Ren, 2009; Sathitbun-anan et al., 2015; Trianni et al., 2017a }\end{array}$ & Simple \\
\hline & Training and education & $\begin{array}{l}\text { IS: Bocken et al., } 2014 \\
\text { OHS: Cagno et al., 2016, } 2011 \\
\text { EcoEff: Ghazilla et al., } 2015 \\
\text { EnEff: Sathitbun-anan et al., 2015; Trianni et al., 2017a }\end{array}$ & Simple \\
\hline$\underline{\text { Information }}$ & $\begin{array}{l}\text { Dialogue and } \\
\text { encouragement }\end{array}$ & $\begin{array}{l}\text { OHS: Cagno et al., 2016; Hasle and Limborg, 2006; Roy et al., 2003; Vecchio- } \\
\text { sadus, } 2007 \\
\text { EnEff: Sathitbun-anan et al., } 2015\end{array}$ & Simple \\
\hline
\end{tabular}




\begin{tabular}{|c|c|c|c|}
\hline & $\begin{array}{l}\text { Trustworthiness, clarity } \\
\text { and availability of } \\
\text { information }\end{array}$ & $\begin{array}{l}\text { OHS: Cagno et al., 2016; Miller and Haslam, } 2009 \\
\text { EcoEff: Ekins, 2005; Ghazilla et al., } 2015 \\
\text { EnEff: Sathitbun-anan et al., 2015; Trianni et al., 2017a }\end{array}$ & Simple \\
\hline \multirow{4}{*}{$\underline{\text { Innovation }}$} & Product innovation & $\begin{array}{l}\text { IS: Arruda et al., 2013; Küçüksayraç, } 2015 \\
\text { EcoEff: Bossle et al., 2016; De Medeiros et al., 2014; Fernández-Viñé et al., } \\
\text { 2013, 2010; Van Hemel and Cramer, } 2002 \\
\text { EnEff: Sathitbun-anan et al., } 2015\end{array}$ & $\begin{array}{l}\text { Enabler } \\
\text { (internal) }\end{array}$ \\
\hline & Technology innovation & $\begin{array}{l}\text { IS: Bocken et al., } 2014 \\
\text { EcoEff: Bossle et al., 2016; Dagiliūtė and Juknys, 2012; De Medeiros et al., } \\
\text { 2014; Del Río González, 2005; Ekins, 2005; Fernández-Viñé et al., 2013, 2010; } \\
\text { Hojnik and Ruzzier, 2016; Mittal et al., 2013; Mittal and Sangwan, 2015; Van } \\
\text { Hemel and Cramer, } 2002 \\
\text { EnEff: Brunke et al., 2014; Johansson and Thollander, 2018; Sathitbun-anan et } \\
\text { al., 2015; Sudhakara Reddy et al., 2014; Venmans, } 2014\end{array}$ & $\begin{array}{l}\text { Enabler } \\
\text { (internal) }\end{array}$ \\
\hline & Quality & $\begin{array}{l}\text { IS: Gabzdylova et al., 2009; Küçüksayraç, } 2015 \\
\text { EcoEff: Fernández-Viñé et al., 2013, 2010; Ghazilla et al., 2015; Van Hemel and } \\
\text { Cramer, } 2002 \\
\text { EnEff: Hasanbeigi et al., 2010; Sathitbun-anan et al., } 2015\end{array}$ & $\begin{array}{l}\text { Enabler } \\
\text { (internal) }\end{array}$ \\
\hline & $\begin{array}{l}\text { Greater efficiency in } \\
\text { processes }\end{array}$ & $\begin{array}{l}\text { IS: Arruda et al., } 2013 \\
\text { EcoEff: Ekins, 2005; Van Hemel and Cramer, } 2002 \\
\text { EnEff: Ren, } 2009\end{array}$ & $\begin{array}{l}\text { Enabler } \\
\text { (internal) }\end{array}$ \\
\hline \multirow[t]{2}{*}{$\underline{\text { Economic }}$} & Cost savings & $\begin{array}{l}\text { IS: Gabzdylova et al., 2009; Kara et al., 2014; Küçüksayraç, 2015; Lloret, 2016; } \\
\text { Lozano, } 2015 \\
\text { OHS: EASHW, } 2010 \\
\text { EcoEff: Altham, 2007; Bossle et al., 2016; Brammer et al., 2012; Del Río } \\
\text { González, 2005; Fernández-Viñé et al., 2013; Ghazilla et al., 2015; Hojnik and } \\
\text { Ruzzier, 2016; Masurel, 2007; Mittal et al., 2013; Mittal and Sangwan, 2015; } \\
\text { Santolaria et al., 2011; Van Hemel and Cramer, 2002 } \\
\text { EnEff: Apeaning and Thollander, 2013; Brunke et al., 2014; De Groot et al., } \\
\text { 2001; Hasanbeigi et al., 2010; Johansson and Thollander, 2018; Lee, 2015; } \\
\text { Sathitbun-anan et al., 2015; Thollander et al., 2013; Thollander and Ottosson, } \\
\text { 2008; Trianni et al., 2017a; Venmans, 2014 }\end{array}$ & $\begin{array}{l}\text { Enabler } \\
\text { (internal) }\end{array}$ \\
\hline & Increasing incomes & $\begin{array}{l}\text { IS: Gabzdylova et al., 2009; Kara et al., 2014; Sy, } 2014 \\
\text { EcoEff: Altham, 2007; Brammer et al., 2012; Hojnik and Ruzzier, } 2016\end{array}$ & $\begin{array}{l}\text { Enabler } \\
\text { (internal) }\end{array}$ \\
\hline
\end{tabular}


